\title{
Fluorous Zirconocene(IV) Complexes and Their Olefin Polymerization Activity in Toluene and Fluorous Biphasic Solvent Systems ${ }^{\dagger}$
}

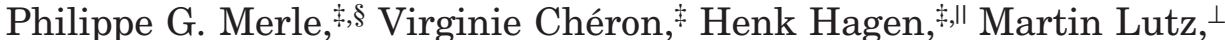 \\ Anthony L. Spek,,$^{\perp}$ Berth-Jan Deelman, ${ }^{*, \#}$ and Gerard van Koten ${ }^{\ddagger}$ \\ Debye Institute, Department of Metal Mediated Synthesis, and Bijvoet Center for Biomolecular \\ Research, Department of Crystal and Structural Chemistry, Utrecht University, \\ Padualaan 8, NL-3584 CH Utrecht, The Netherlands, and ARKEMA Vlissingen BV, \\ P.O. Box 70, NL-4380 AB Vlissingen, The Netherlands
}

Received July 4, 2004

\begin{abstract}
The synthesis $(\mathbf{4 a}-\mathbf{d})$ and structure $(\mathbf{4 a}, \mathbf{c})$ of the four crystalline, water-stable, hydrocarbon- and perfluorocarbon (PFC)-soluble fluorous zirconocene(IV) dichloride precatalysts [Zr$\left.\left\{\eta^{5}-\mathrm{C}_{5} \mathrm{H}_{4} \mathrm{SiMe}_{3-n}\left(\mathrm{R}_{\mathrm{F}}\right)_{n}\right\}_{2} \mathrm{Cl}_{2}\right]\left(n=1, \mathrm{R}_{\mathrm{F}}=\mathrm{CH}_{2} \mathrm{CH}_{2} \mathrm{C}_{6} \mathrm{~F}_{13}(\mathbf{4 a}), \mathrm{C}_{8} \mathrm{~F}_{17}(\mathbf{4 b}), \mathrm{CH}_{2} \mathrm{C}_{6} \mathrm{~F}_{5}(\mathbf{4} \mathbf{c}) ; n=3\right.$, $\mathrm{R}_{\mathrm{F}}=\mathrm{CH}_{2} \mathrm{C}_{6} \mathrm{~F}_{5}$ (4d)), possessing one to three fluorous alkyl or aryl groups attached to the cyclopentadienyl ligand through a silicon atom and an additional methylene (4c,d) or ethylene (4a) spacer or no spacer at all (4b), are reported. A nonfluorous analogue of $\mathbf{4 a},\left[\mathrm{Zr}\left\{\eta^{5}-\mathrm{C}_{5} \mathrm{H}_{4^{-}}\right.\right.$ $\left.\mathrm{SiMe}_{2} \mathrm{C}_{8} \mathrm{H}_{17}\right\}_{2} \mathrm{Cl}_{2}$ ] (4e), was prepared for comparison, and $\mathbf{4 a}$ was easily converted to its dimethyl derivative $\left[\mathrm{Zr}\left\{\eta^{5}-\mathrm{C}_{5} \mathrm{H}_{4} \mathrm{SiMe}_{2} \mathrm{CH}_{2} \mathrm{CH}_{2} \mathrm{C}_{6} \mathrm{~F}_{13}\right\}_{2} \mathrm{Me}_{2}\right]$ (5a). The ethylene polymerization activities of the zirconocene dichlorides were compared to those of the known bis$\{$ (trimethylsilyl)cyclopentadienyl $\}$ zirconium dichloride $\left[\mathrm{Zr}\left\{\eta^{5}-\mathrm{C}_{5} \mathrm{H}_{4} \mathrm{SiMe}_{3}\right\}_{2} \mathrm{Cl}_{2}\right]$ (4f), in both toluene and fluorous biphasic solvent (FBS) systems. In the case of $\mathbf{4 b}$ a PE with a bimodal molecular weight distribution and a significantly lower molecular weight was obtained. Polymerization data and polymer properties for $\mathbf{4 a}-\mathbf{d}$, compared to data for $\mathbf{4 f}$, show a marked influence of the fluorous groups and the alkyl spacer (e.g. methylene in $\mathbf{4 c}$ or ethylene in 4a). FBS conditions result in PE with a higher average molecular weight. Evidence on the nature of the active species formed when these precatalysts were treated with an excess of methylaluminoxane (MAO) is presented.
\end{abstract}

\section{Introduction}

Fluorous phase catalysis using fluorinated catalysts in a fluorous biphasic solvent system (FBS; i.e., a mixture of hydrocarbon and perfluorocarbon-PFCsolvents) is of considerable interest, mainly in relation to catalyst recycling. ${ }^{1}$ In addition, PFC's have also received attention because of their unique solvent properties (low polarity, inertness, low dielectric constant, high solubility of gases, low heats of evaporation). They offer advantages in terms of environmental considerations (nontoxic) and, in the case of polymerization reactions, improved properties of the polymers. ${ }^{2}$

* To whom correspondence should be addressed. Fax: +31 113 612984. E-mail: berth-jan.deelman@arkemagroup.com.

Dedicated to Professor Jan H. Teuben at the occasion of his retirement and in recognition of his important contributions to the field of early-transition-metal chemistry and $\alpha$-olefin polymerization catalysis.

$¥$ Debye Institute, Utrecht University.

$\S$ Current address: The CHEM Lab, Concordia University, 7141 Sherbrooke West, Montreal H4B 1R6, QC, Canada.

"Current address: Dow Benelux B.V, P.O. Box 48, 4530 AA Terneuzen, The Netherlands.

${ }^{\perp}$ Bijvoet Center for Biomolecular Research, Utrecht University.

* ARKEMA Vlissingen BV.

(1) (a) De Wolf, E.; van Koten, G.; Deelman, B. J. Chem. Soc. Rev. 1999, 28, 37-41. (b) Hope, E. G.; Stuart, A. M. J. Fluorine Chem. 1999 100, 75-83. (c) Horváth, I. T. Acc. Chem. Res. 1998, 31, 641-650. (d) Curran, D. P. Angew. Chem., Int. Ed. 1998, 37, 1175-1196. (e) Cornils, B. Angew. Chem., Int. Ed. 1997, 36, 2057-2059. (f) Barthel-Rosa, L. P.; Gladysz, J. A. Coord. Chem. Rev. 1999, 190-192, 587-605.
We are here interested in fluorous metallocene based olefin polymerization precatalysts. Olefin polymerization catalysts consisting of group 4 metallocene dichloride precatalysts and methylaluminoxane (MAO) have received significant industrial interest. ${ }^{3}$ They belong to the most highly active and selective classes of catalysts for $\alpha$-olefin polymerization, and they offer unique possibilities for controlling polymer structure and properties. ${ }^{4}$ While catalyst recovery is not a major issue in coordination polymerization (low catalyst loading), we reasoned that the fluorous character of the catalyst, optionally supplemented by a fluorous reaction medium (pure PFC solvent or FBS conditions), would affect the polymerization mechanism and could possibly lead to improved physical properties of the polymers produced. Examples of coordination polymerization in PFC solvents are extremely rare, ${ }^{5}$ despite their interesting solvent properties that are related to those of super-

(2) Banks, R. E., Smart, B. E., Tatlow, J. C., Eds. Organofluorine Chemistry, Principles and Commercial Applications; Plenum Press: New York, 1994, Chapter 3, pp 57-67.

(3) For recent reviews, see e.g.: (a) Marks, T. J., Stevens, J. C., Eds. Topics in Catalysis; Baltzer: Amsterdam, 1999; Vol. 7, pp 1-208. (b) Kaminsky, W., Ed. Metalorganic Catalysts for Synthesis and Polymerization; Springer-Verlag: Berlin, 1999. (c) Kaminsky, W.; Laban, A. Appl. Catal. A: Gen. 2001, 222, 47-61. (d) Jordan, R. F. Ed. J. Mol. Catal. 1998, 128, 1-337.

(4) (a) Coates, G. W. Chem. Rev. 2000, 100, 1223-1252 and references therein. (b) Morse, P. M. Chem. Eng. News 1973, 51(July 6), 11-16. 


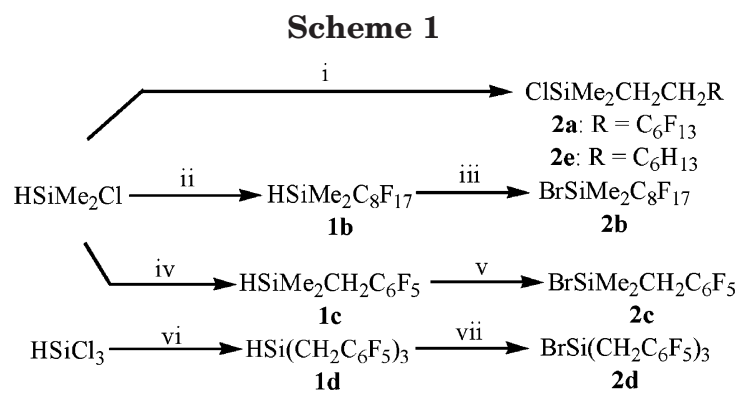

Reagents and conditions: i, $\mathrm{RCH}=\mathrm{CH}_{2}, \mathrm{RhCl}\left(\mathrm{PPh}_{3}\right)_{3}(5 \%)$, toluene, reflux; ii, $\mathrm{C}_{8} \mathrm{~F}_{17} \mathrm{I}, \mathrm{LiBu}^{\mathrm{n}}, \mathrm{Et}_{2} \mathrm{O} ;-78^{\circ} \mathrm{C}$; iii, $\mathrm{Br}_{2}, \mathrm{CCl}_{4}, 60^{\circ} \mathrm{C}$; iv, $\mathrm{C}_{6} \mathrm{~F}_{5} \mathrm{CH}_{2} \mathrm{Br}, \mathrm{Mg}, \mathrm{Et}_{2} \mathrm{O}, 25$ ${ }^{\circ} \mathrm{C}$; v, $\mathrm{Br}_{2}$, pentane, $25^{\circ} \mathrm{C}$; vi, $\mathrm{C}_{6} \mathrm{~F}_{5} \mathrm{CH}_{2} \mathrm{Br}, \mathrm{Mg}, \mathrm{Et}_{2} \mathrm{O}, 25^{\circ} \mathrm{C}$; vii, $\mathrm{Br}_{2}$, hexane, 25 ${ }^{\circ} \mathrm{C}$

critical $\mathrm{CO}_{2}$ but available at atmospheric pressure (in contrast to $\left.s c-\mathrm{CO}_{2}\right)_{.}^{1 \mathrm{c}, 2,6}$

Finally, it should be noted that although the cyclopentadienyl group is one of the most ubiquitous ligands in organometallic chemistry, only a few such ligands bearing fluorine or short fluoroalkyl substituents have been reported. ${ }^{7}$ Notably in these complexes, the electronic effect of the fluorous group on the metal center is significant, as it is directly bound to a metalcoordinated carbon atom. We here report on the synthesis $(\mathbf{4 a}-\mathbf{d})$ and structure $(\mathbf{4 a}, \mathbf{c})$ of the four crystalline, hydrocarbon- and PFC-soluble fluorous zirconocene(IV) dichlorides $\left[\mathrm{Zr}\left\{\eta^{5}-\mathrm{C}_{5} \mathrm{H}_{4}\left(\mathrm{SiMe}_{3-n}\left(\mathrm{R}_{\mathrm{F}}\right)_{n}\right)\right\}_{2} \mathrm{Cl}_{2}\right](n$ $=1, \mathrm{R}_{\mathrm{F}}=\mathrm{CH}_{2} \mathrm{CH}_{2} \mathrm{C}_{6} \mathrm{~F}_{13}(\mathbf{4 a}), \mathrm{C}_{8} \mathrm{~F}_{17}(\mathbf{4 b}), \mathrm{CH}_{2} \mathrm{C}_{6} \mathrm{~F}_{5}(\mathbf{4})$; $\left.n=3, \mathrm{R}_{\mathrm{F}}=\mathrm{CH}_{2} \mathrm{C}_{6} \mathrm{~F}_{5}(\mathbf{4 d})\right)$ and some first investigations into their olefin polymerization activity in both conventional and fluorous biphasic systems (FBS) upon treatment with MAO as cocatalyst. Part of this work was previously communicated. ${ }^{8}$ More recently, the synthesis of related titanium compounds was reported ${ }^{9}$ and there has been work by the Gladysz group on (2-(perfluoroalkyl)ethyl)cyclopentadienyl complexes. ${ }^{10}$

\section{Results and Discussion}

Synthesis of the Fluorous Zirconocene Dichlorides $4 a-d$ and Non-Fluorous 4 e. The chosen precursors for the zirconocene dichlorides $4 \mathbf{a}-\mathbf{e}$, the fluorous halosilanes $\mathbf{2 a}-\mathbf{d}$ and nonfluorous $\mathbf{2 e}$, were synthesized in good to quantitative yield (Scheme 1).

(5) (a) Malanga, M. T.; Newman, T. H. Eur. Pat. Appl. EP 361309 A2, 1990, (b) Jones, E.; Walker, J. Ger. Offen. DE 2501239, 1975. (c) Mitani, M.; Furuyama, R.; Mohri, J.-I.; Saito, J.; Ishii, S.; Terao, H.; Nakano, T.; Tanaka, H.; Fujita T. J. Am. Chem. Soc. 2003, 125, 42934305.

(6) (a) De Vries, T. J.; Duchateau, R.; Vorstman, M. A. G.; Keurentjes, J. T. F. Chem. Commun. 2000, 263-264. (b) Kendall, J. L.; Canelas, D. A.; Young, J. L.; DeSimone, J. M. Chem. Rev. 1999, 99, 543-563. (7) (a) Hughes, R. P.; Trujillo, H. A. Organometallics 1996, 15, 286294. (b) Herrera, V.; de Rege, P. J. F.; Horváth, I. T.; Le Husebo, T.; Hughes, R. P. Inorg. Chem. Commun. 1998, 1, 197-199. (c) Maldanis, R. J.; Chien, J. C. W.; Rausch, M. D. J. Organomet. Chem. 2000, 599 107-111. (d) Deck, P. A.; Jackson, W. F.; Fronczek, F. R. Organometallics 1996, 15, 5287-5291. (e) Bříza, T.; Kvíčala, J.; Paleta, O. Cermák, J. Tetrahedron 2002, 58, 3841-3846.

(8) (a) Cheron, V.; Couturier, J.-L.; Hagen, H.; van Koten, G.; Deelman, B. J. Int. Pat. Appl. WO/0214337 (publication date Feb 21, 2002) to ATOFINA. (b) Merle, P. G.; Deelman, B. J.; van Koten, G. Fluorous metallocenes for $\alpha$-olefin polymerisation in fluorous biphasic systems. Second European Catalysis Symposium; Organic Catalysis for a Sustainable Development; Sept 23-26, 2001, Pisa, Italy; Book of Abstracts, Poster 48.

(9) Čermák, J.; Štástná, L.; Sýkora, J.; Císařová, I.; Kvíčala, J. Organometallics 2004, 23, 2850-2854 and references therein.

(10) Dinh, L. V.; Gladysz, J. A. Chem. Commun. 2004, 998-999 and references therein.

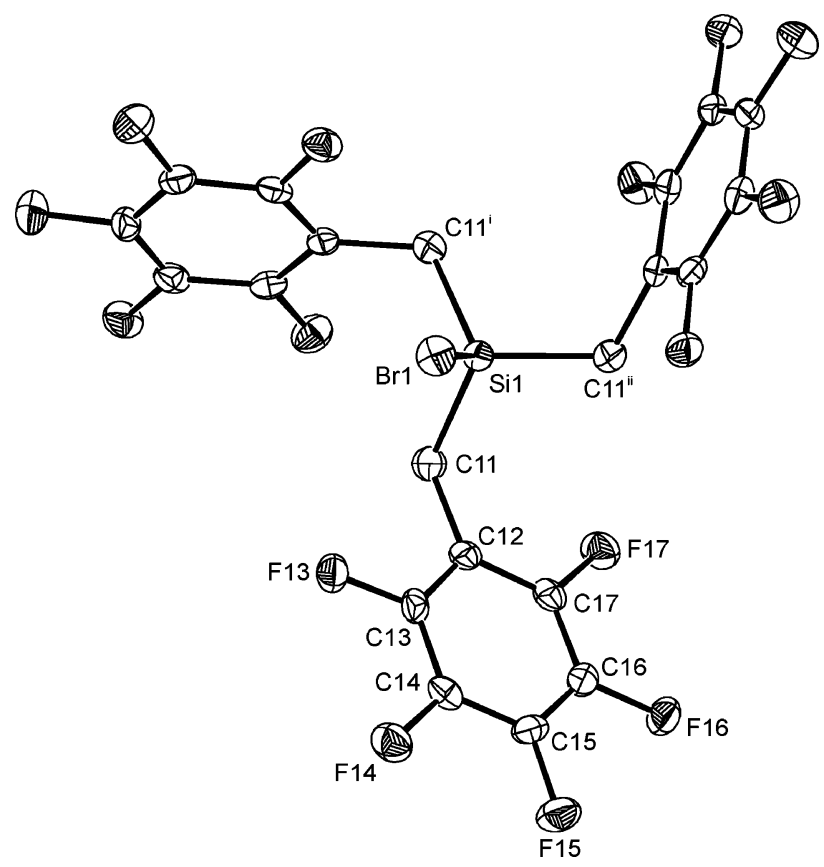

Figure 1. One of the two independent molecules of compound 2d. Displacement ellipsoids are drawn at the $50 \%$ probability level, and $\mathrm{H}$ atoms are omitted for clarity. Symmetry operations: (i) $1-y, 1+x-y, z$; (ii) $-x+y, 1$ $-x, z$. Selected bond lengths $(\AA): \mathrm{Si}-\mathrm{Br}=2.2192(15)$, 2.1971(14); $\mathrm{Si}-\mathrm{C} 11=1.864(3), 1.876(3)$. Selected bond angles (deg): $\mathrm{Br}-\mathrm{Si}-\mathrm{C} 11=108.37(10), 109.46(9), \mathrm{C} 11-$ $\mathrm{Si}-\mathrm{C} 11 \mathrm{i}=110.55(9), \quad 109.48(9) ; \quad \mathrm{Si}-\mathrm{C} 11-\mathrm{C} 12=$ 114.41(19), 115.18(18).

The chlorosilane $\mathbf{2 a}$ (step i of Scheme 1) is prepared by catalytic hydrosilylation of the 1,1,2-trihydroperfluorooctene using fluorous biphasic extraction of $\mathbf{2 a}$, allowing complete recovery of the expensive rhodium catalyst. ${ }^{11}$ The fluorous silanes $\mathbf{2} \mathbf{b}-\mathbf{d}$ were obtained in two steps from the commercially available perfluorooctyl iodide (for 2b) or 2,3,4,5,6-pentafluorobenzyl bromide (for $\mathbf{2 c}, \mathbf{d}$ ). The intermediate silanes $\mathbf{1 b}-\mathbf{d}$, obtained through modified literature procedures ${ }^{12}$ (steps ii, iv, and vi of Scheme 1, respectively), were brominated into $\mathbf{1 b}-\mathbf{d}$ (steps iii, v, and vii of Scheme 1, respectively).

Crystallization of $\mathbf{2 d}$ from $\mathrm{Et}_{2} \mathrm{O}$ at $-20{ }^{\circ} \mathrm{C}$ gave colorless crystals suitable for single-crystal X-ray analysis. The molecular structure is shown in Figure 1, along with selected bond distances and angles. The asymmetric unit contains one-third of each of the two independent molecules, both of which have crystallographic $C_{3}$ symmetry with the symmetry axis along the $\mathrm{Si}-\mathrm{Br}$ bond. Despite the heavy fluorination at the phenyl rings the $\mathrm{Si}-\mathrm{Br}$ bond distances of 2.2192(15) and 2.1971(14) $\AA$ are comparable to those in $\mathrm{Me}_{3} \mathrm{SiBr}^{13}$ and 1,4-dibromo-1,4-disilabutane $(2.2362(12) \AA)^{14}$ but shorter than in tris(bromodimethylsilyl)methane (2.251-2.263

(11) De Wolf, E.; Spek, A. L.; Deelman, B. J.; van Koten, G. Organometallics 2001, 20, 3686-3690.

(12) (a) Denson, D. D.; Smith, C. F.; Tamborski, C. J. Fluorine Chem. 1973/1974, 3, 247. (b) Smith, C. F.; Soloski, E. J.; Tamborski, C. J. Fluorine Chem. 1974, 4, 35. (c) Thoai, N. J. Fluorine Chem. 1975, 5, 115. (d) Picard, J. P.; Ekouya, A.; Dunogues, J.; Duffaut, N.; Calas, R J. Organomet. Chem. 1975, 93, 51-70.

(13) Harmony, M. D.; Strand, M. R. J. Mol. Spectrosc. 1980, 81, 308315 .

(14) Mitzel, N. W.; Riede, J.; Schmidbauer, H. Acta Crystallogr. 1996, C52, 980-982. 


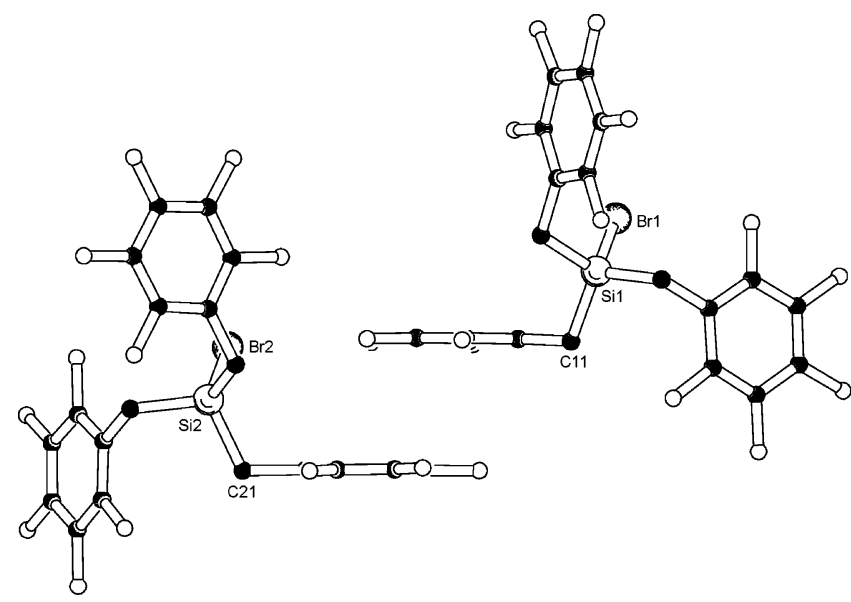

Figure 2. Stacking between the pentafluorophenyl rings of the two independent molecules of $\mathbf{2 d}$. The rings are nearly parallel with a dihedral angle of $0.02^{\circ}$. The interplanar distance is approximately $3.14 \AA$. Because the rings are shifted with respect to each other, the distance between the ring centers is significantly longer (4.2098(17) ̊). Due to this shift, atom F16 of ring 1 is above the center of ring 2 (distance F16- $\mathrm{Cg} 02=3.121(2) \AA$ ). Atoms F25 and F26 of ring 2 are directly above carbon atoms C17 and C15 of

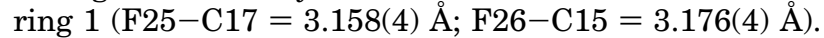

\section{Scheme 2}
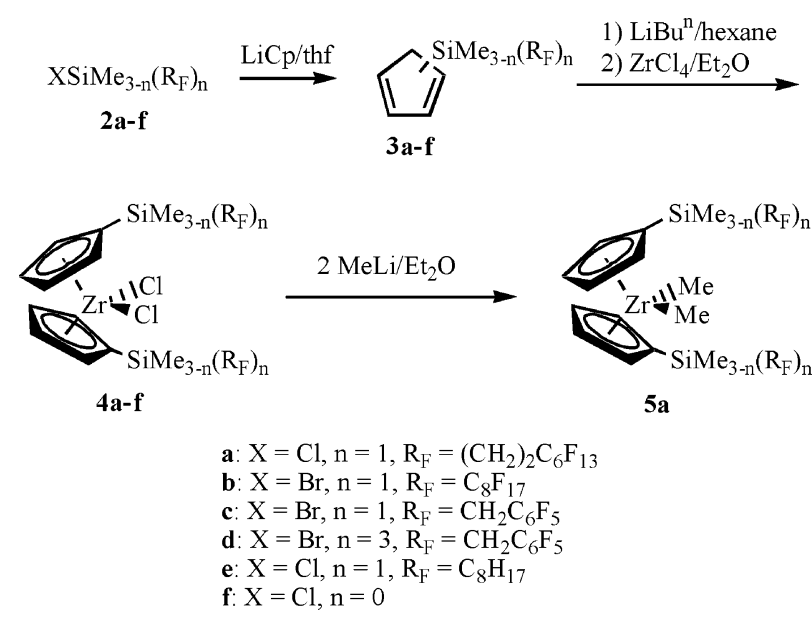

A). ${ }^{15} \mathrm{Also}$, the tetrahedral hybridization of the Si atoms with angles of $108.37(10)-110.55(9)^{\circ}$ is comparable to that in other bromotrialkylsilanes and compounds $\mathbf{4 a , c}$ (vide infra). Interestingly, the pentafluorophenyl rings of the two independent molecules of $\mathbf{2 d}$ are $\pi$-stacked but with significant ring slippage (Figure 2).

The target compounds $\mathbf{4 a}-\mathbf{e}$ were prepared (Scheme 2) by slight modification of a reported procedure for [Zr$\left.\left(\eta^{5}-\mathrm{C}_{5} \mathrm{H}_{4} \mathrm{SiMe}_{3}\right)_{2} \mathrm{Cl}_{2}\right](\mathbf{4 f}) .{ }^{16}$ Addition of $\mathrm{LiCp}\left(\mathrm{Cp}=\mathrm{C}_{5} \mathrm{H}_{5}\right)$ in THF to $\mathbf{2 a}-\mathbf{e}$ gave in good yield the fluorous silylsubstituted cyclopentadienes $\mathbf{3 a}-\mathbf{e}$ as a mixture of the 1-, 2- and 5-silyl isomers (the last being the major species by ca. 80\%). ${ }^{17}$ Lithiation and reaction with solid $\mathrm{ZrCl}_{4}$ produced the new fluorous zirconocene(IV) dichlorides $\mathbf{4 a}-\mathbf{e}$ in moderate to good yields as colorless $(\mathbf{4 a})$, off-white $(\mathbf{4 c}, \mathbf{d})$, or pale yellow (4b) air-stable, highly

(15) Friesen, D. M.; McDonald, R.; Rosenberg, L. Can. J. Chem. 1999, 77, 1931-1940.

(16) Lappert, M. F.; Pickett, C. J.; Riley, P. I.; Yarrow, P. I. W. J. Chem. Soc., Dalton Trans. 1981, 3, 805-813.

(17) Abel, E. W.; Dunster, M. O. J. Organomet. Chem. 1971, 33, 161-167. hydrocarbon-soluble, crystalline solids or as a brown oil (4e) with satisfactory analyses and multinuclear ambient-temperature NMR spectra. Complex 4a was easily converted to its dimethyl derivative $\left[\left(\eta^{5}-\mathrm{C}_{5} \mathrm{H}_{4} \mathrm{SiMe}_{2} \mathrm{CH}_{2^{-}}\right.\right.$ $\left.\left.\mathrm{CH}_{2} \mathrm{C}_{6} \mathrm{~F}_{13}\right)_{2} \mathrm{ZrMe}_{2}\right]$ (5a).

Low-temperature NMR spectra (300 MHz) of toluene$d_{8}$ solutions of $4 \mathbf{a}, \mathbf{c}$ were recorded from 25 to $-80{ }^{\circ} \mathrm{C}$ (for assignments, see the Experimental Section) and revealed that even at low temperature $\left(-80{ }^{\circ} \mathrm{C}\right)$ the fluxional $\mathrm{M}-\mathrm{Cp}$ rotational processes are still operative and fast on the NMR time scale. ${ }^{18}$ The spectra recorded under the same conditions for the precatalyst $\mathbf{4 b}$ (i.e. with the $\mathrm{C}_{8} \mathrm{~F}_{17}$ tail; see the Experimental Section for assignments) merit more explanations: the $\alpha$ - and $\beta$-proton signals, of the monosubstituted-cyclopentadienyl ligand ( $\delta 6.30$ and 5.70 at ambient temperature), gradually disappear to the profit of four equal-intensity signals $\left(\delta 6.34,6.15,5.64\right.$, and 5.46 at $\left.-80{ }^{\circ} \mathrm{C}\right)$; in the meantime, the singlet observed for the $\mathrm{SiMe}_{2}$ protons ( $\delta 0.61$ at ambient temperature) splits into two new signals at $\delta 0.75$ and 0.67 at $-80{ }^{\circ} \mathrm{C}$, the fluxional $\mathrm{M}-\mathrm{Cp}$ rotational process becoming slower than the NMR time scale, indicative of either a $C_{2^{-}}$or $C_{v^{-}}$ symmetric isomer (rac or meso forms).

Complexes $4 \mathbf{a}-\mathbf{d}$ have a much higher hydrocarbon solubility than the previously reported group 4 fluorous metallocenes $\left[\mathrm{M}\left\{\eta^{5}-\mathrm{C}_{5} \mathrm{H}_{4}\left(\mathrm{C}_{6} \mathrm{~F}_{5}\right)\right\}_{2} \mathrm{Cl}_{2}\right]\left(\mathrm{M}=\mathrm{Ti},{ }^{7 \mathrm{~b}} \mathrm{Zr}^{7 \mathrm{c}}\right)$. Moreover, in contrast to $\mathbf{4 f}$, they clearly display, albeit modest, solubility in PFC solvents: e.g., FC-72 (ca. 1 $\mathrm{g} / \mathrm{L})$. The partition coefficient $P\left(P=C_{\text {fluorous phase }}\right.$

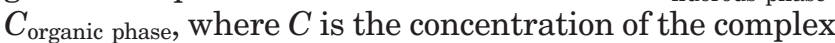
in the solvent, i.e. $c-\mathrm{C}_{6} \mathrm{~F}_{11} \mathrm{CF}_{3}$ and toluene, respectively) for complexes $\mathbf{4 a}-\mathbf{c}$ reflected a trend similar to that observed in the case of fluorous phosphines, ${ }^{19}$ i.e., a steady increase with the $\mathrm{F}$ weight percentage of the molecule (cf. $P_{4 \mathrm{c}}=0.09$, wt $\% \mathrm{~F} 24.7 ; P_{4 \mathrm{a}}=0.23$, wt $\%$ F $44.9 ; P_{4 b}=0.78$, wt $\%$ F 51.9); these values indicate a relatively small affinity of the molecules for the fluorous phase but possibly enough to induce surface activity. ${ }^{20}$

Crystal Structures of $4 a-c$. Compounds $4 a, c$ were successfully subjected to structural characterization by single-crystal X-ray crystallography. The single crystals of $\mathbf{4 a}, \mathbf{c}$ contained discrete $\left[\mathrm{Zr}\left\{\eta^{5}-\mathrm{C}_{5} \mathrm{H}_{4}\left(\mathrm{SiMe}_{2} \mathrm{R}_{\mathrm{F}}\right)\right\}_{2} \mathrm{Cl}_{2}\right]$ molecules $\left(\mathrm{R}_{\mathrm{F}}=\mathrm{CH}_{2} \mathrm{CH}_{2} \mathrm{C}_{6} \mathrm{~F}_{13}\right.$ (4a) $\mathrm{CH}_{2} \mathrm{C}_{6} \mathrm{~F}_{5}$ (4c) $)$ (Figures 3 and 4, respectively). Compound $4 \mathbf{b}$ could not be refined satisfactorily, due to significant disorder in the perfluorooctyl groups $(R=22 \%)$; hence, the crystallographic data are not reported here. However, we can conclude from this analysis that $\mathbf{4 b}$ also has a regular bent-metallocene structure, similar to that of $\mathbf{4 a}$. The asymmetric unit for $\mathbf{4 c}$ contained a single molecule, whereas it contained half a molecule in $\mathbf{4 a}$, the other half being generated by a 2 -fold rotation. The stereochemistry around the Zr atom was invariably that found in previously studied bent-sandwich complexes of the type $\left[\mathrm{ML}_{2} \mathrm{X}_{2}\right]\left(\mathrm{M}=\mathrm{Zr}\right.$, Hf; $\mathrm{L}=\eta^{5}$-cyclopentadienyl or

(18) DSC analysis of crystalline $\mathbf{4 a}, \mathbf{c}$ in the solid state, from ambient temperature to the melting point, shows no evidence of polymorphism as one could have expected with such fluxional groups (e.g. $\mathrm{CH}_{2}$ $\mathrm{CH}_{2} \mathrm{C}_{6} \mathrm{~F}_{13}$ as in $\mathbf{4 a}$ ).

(19) Richter, B.; de Wolf, E.; van Koten, G.; Deelman, B. J. J. Org. Chem. 2000, 65, 3885-3893.

(20) de Wolf, E.; Spek, A. L.; Kuipers, B. W. M.; Philipse, A. P.; Meeldijk, J. D.; Boumans B. H. H.; Frederic, P. M.; Deelman, B. J.; van Koten, G. Tetrahedron 2002, 58, 3911-3922. 


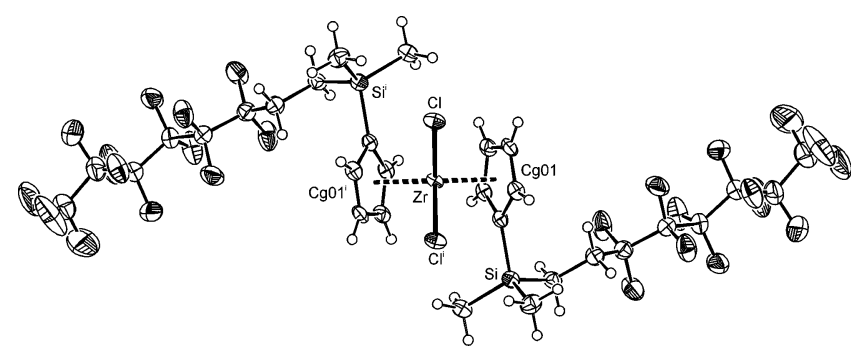

Figure 3. Molecular structure of compound 4a. Displacement ellipsoids are drawn at the $50 \%$ probability level, and $\mathrm{H}$ atoms are omitted for clarity. Symmetry operation: (i) $-x, y, 0.5-z$. Selected bond lengths $(\AA)$ and angles (deg): $\mathrm{Zr}-\mathrm{Cl}=2.4524(7), \mathrm{Zr}-\mathrm{Cg} 01=2.1987(12) ; \mathrm{Cl}-\mathrm{Zr}-\mathrm{Cl}^{\prime}=$ 96.50(3), $\mathrm{Cg} 01-\mathrm{Zr}-\mathrm{Cg} 01^{\prime}=129.61(5)$.

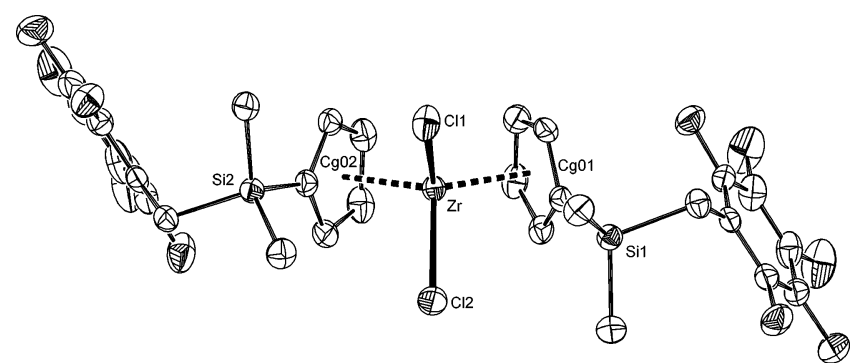

Figure 4. Molecular structure of compound 4c. Displacement ellipsoids are drawn at the $50 \%$ probability level, and $\mathrm{H}$ atoms are omitted for clarity. Selected bond lengths $(\AA)$ and angles (deg): $\mathrm{Zr}-\mathrm{Cl} 1=2.4571(6), \mathrm{Zr}-\mathrm{Cl} 2=$ 2.4379(6), $\mathrm{Zr}-\mathrm{Cg} 01=2.2091(11), \mathrm{Zr}-\mathrm{Cg} 02=2.2157(11)$; $\mathrm{Cl} 1-\mathrm{Zr}-\mathrm{Cl} 2=99.48(2), \mathrm{Cg} 01-\mathrm{Zr}-\mathrm{Cg} 02=127.94(4)$.

an analogue $)^{21}$ and can be conveniently described as a distorted tetrahedron by considering the ligand $\mathrm{L}^{-}$as a sterically demanding unidentate moiety. The cyclopentadienyl ring is slightly asymmetrically $\eta^{5}$-bonded to the $\mathrm{Zr}$ atom (with $\mathrm{Zr}-\mathrm{C}$ distances ranging from 2.480(3) to $2.530(3) \AA$ in $\mathbf{4 a}$ and from $2.489(2)$ to $2.545(2) \AA$ in $\mathbf{4 c}$, the shift resulting from the steric hindrance of the bulky $\mathrm{SiMe}_{2} \mathrm{CH}_{2} \mathrm{CH}_{2} \mathrm{C}_{6} \mathrm{~F}_{13}$ group) with similar $\mathrm{Zr}$-centroid distances $(\mathrm{Zr}-\mathrm{Cg}=2.1987(12) \AA$ in $\mathbf{4 a}$ and 2.2091(11) and $2.2157(11) \AA$ in $\mathbf{4 c}$ ).

Compound 4 a possess 2 -fold symmetry in the solid state (Figure 3 ) with the Si atoms pointing in opposite directions, as observed for the related complex $\mathbf{4 f}$ with a smaller $\mathrm{SiMe}_{3}$ substituent. ${ }^{22}$ The fluorous tails lie on one side of the molecule, the two chlorine atoms occupying the other one. The Si atoms are pushed above the cyclopentadienyl plane by $0.335(1) \AA$, resulting in a $\mathrm{Cg} 01-\mathrm{Zr}-\mathrm{Cg}_{01} 1^{\prime}$ angle of $129.61(5)^{\circ}$ (cf. $129.1^{\circ}$ for $\left.\mathbf{4 f}\right){ }^{22}$ The $\mathrm{Cl}-\mathrm{Zr}-\mathrm{Cl}^{\prime}$ angle of $96.50(3)^{\circ}$ is wider than in $\mathbf{4 f}$ $\left(93.7^{\circ}\right)$ but close to the $97^{\circ}$ measured for the catalytically highly active zirconocene dichloride complex $\left[\operatorname{Zr}\left\{\eta^{5}\right.\right.$ $\mathrm{C}_{5} \mathrm{H}_{5}{ }_{2} \mathrm{Cl}_{2}$ ].

Triclinic 4c crystallized as the rac conformer with $C_{1}$ symmetry (Figure 4). In contrast to $\mathbf{4 a}$, the Si atoms on the $\mathrm{Cp}$ rings in $\mathbf{4 c}$ are eclipsed with astride $\mathrm{Cl}$ atoms, as observed for $\left[\mathrm{Zr}\left\{\eta^{5}-\mathrm{C}_{5} \mathrm{H}_{4} \mathrm{CH}_{2} \mathrm{Ph}\right\}_{2} \mathrm{Cl}_{2}\right]^{23}$ or the geo-

(21) Cardin, D. J., Lappert, M. F., Raston, C. L., Eds. Chemistry of Organo Zirconium and Hafnium Compounds; Ellis Hoorwood: Chichester, U.K., 1986.

(22) Antiñolo, A.; Lappert, M. F.; Singh, A.; Winterborn, D. J. W.; Engelhardt, L. M.; Raston, C. L.; White, A. H.; Carty, A. J.; Taylor, N. J. J. Chem. Soc., Dalton Trans. 1987, 1463-1472.

(23) Dusausoy, Y.; Protas, J.; Renaut, P.; Gautheron, B.; Tainturier, G. J. Organomet. Chem. 1978, 157, 167-172.
Table 1. Polymerization Activities for $4 a-d, f$ in Toluene $^{a}$

\begin{tabular}{cccc}
\hline & & \multicolumn{2}{c}{ activity $\left(\mathrm{kg}\right.$ of $\mathrm{PE}((\mathrm{mol} \text { of } \mathrm{Zr}) \mathrm{h})^{-1}$} \\
\cline { 3 - 4 } entry & precatalyst & $t=5 \mathrm{~min}$ & $t=30 \mathrm{~min}$ \\
\hline 1 & $\mathbf{4 a}$ & & 443 \\
2 & $\mathbf{4 b}$ & \multirow{2}{*}{1196} & 234 \\
3 & $\mathbf{4 c}$ & & 288 \\
4 & $\mathbf{4 d}$ & 1125 & 20 \\
5 & $\mathbf{4 f}$ & & $188^{b}$
\end{tabular}

${ }^{a}$ Polymerizations were conducted using $[\mathrm{Zr}]=2.5 \times 10^{-4} \mathrm{~mol}$ $\mathrm{L}^{-1}, \mathrm{Al} / \mathrm{Zr}=500, p=1 \mathrm{bar}$, and $T=20^{\circ} \mathrm{C}$. The reproducibility determined from two experiments was better than $10 \%{ }^{b}$ This catalytic system is essentially deactivated after 5 min due to high viscosity.

metrically constrained $\left[\mathrm{Zr}\left\{\left(\eta^{5}-\mathrm{C}_{5} \mathrm{H}_{4} \mathrm{CH}_{2}\right)_{2} \mathrm{CH}_{2}\right\} \mathrm{Cl}_{2}\right] .{ }^{24}$ The $\mathrm{Cl}-\mathrm{Zr}-\mathrm{Cl}$ bond angle is $99.48(2)^{\circ}$ (cf. $93.7(1)^{\circ}$ in $\left.\mathbf{4 f}\right)$, close to the $97^{\circ}$ reported value in $\left[\mathrm{Zr}\left\{\left(\eta^{5}-\mathrm{C}_{5} \mathrm{H}_{4} \mathrm{CH}_{2}\right)_{2^{-}}\right.\right.$ $\left.\left.\mathrm{CH}_{2}\right\} \mathrm{Cl}_{2}\right],{ }^{24}$ while the $\mathrm{Cg} 01-\mathrm{Zr}-\mathrm{Cg} 02$ bond angle is less influenced at $127.94(4)^{\circ}$ (cf. $129.1^{\circ}$ in $\mathbf{4 f}$ ).

Polymerization Experiments. Our next concern was whether the fluorous zirconocene dichlorides $\mathbf{4 a - d}$ would be at all active in ethylene polymerization using MAO as the cocatalyst. ${ }^{25}$ Initial experiments were carried out at $p=6$ bar, $T=80{ }^{\circ} \mathrm{C},[\mathrm{Zr}]=50 \mu \mathrm{M}, \mathrm{Al} / \mathrm{Zr}$ $=500$, and $t=30 \mathrm{~min}$. Under these conditions the fluorous precatalysts $\mathbf{4 a}, \mathbf{b}$ and nonfluorous 4 e were found to display similar activities, compared to the known reference systems $\mathrm{Cp}_{2} \mathrm{ZrCl}_{2}$ and $(\mathrm{CpBu})_{2} \mathrm{ZrCl}_{2}$ $\left((1.6-2.0) \times 10^{3} \mathrm{~kg}\right.$ of $\left.\mathrm{PE} \mathrm{mol}{ }^{-1} \mathrm{bar}^{-1} \mathrm{~h}^{-1}\right)$. The fact that 4a,e displayed essentially equal activities indicates that the perfluoroalkyl group is effectively insulated from the cyclopentadienyl ligand by the $-\mathrm{SiMe}_{2} \mathrm{CH}_{2} \mathrm{CH}_{2}-$ spacer functionality. Due to the high activity of these precatalysts, the reproducibility and temperature control during the polymerization runs was too poor to allow an accurate comparison of the molecular weights of the polymers obtained. We therefore studied complexes $\mathbf{4 a -}$ d,f under less forcing conditions at 1 bar of ethylene pressure, room temperature, and $[\mathrm{Zr}]=25 \mathrm{mM}$. The activities that were obtained are an order of magnitude lower, but the reproducibility and temperature control were significantly better, allowing comparison of the performance of the different complexes and the properties of the resulting polymers.

Table 1 compares the measured activities for $\mathbf{4 a}-\mathbf{d}, \mathbf{f}$ in toluene. The polymerization times employed are rather long, as we were interested in the evolution of the catalytic activity over time. Remarkably, complex 4f, which was used as the reference system, shows very high activity over the first $5 \mathrm{~min}$, after which stirring became hindered, resulting in significant mass transfer limitation and a reduced activity over $30 \mathrm{~min}$. Complexes $4 \mathbf{a}-\mathbf{c}$, although less active by a factor of 2 , remained active during this $30 \mathrm{~min}$, resulting in higher overall productivity. The highest activity over $30 \mathrm{~min}$ was observed for ethylene-spaced 4a. Substitution of the ethylene function by a tetrafluoroethylene bridge as in 4b induced a 2-fold drop in activity. Apparently an ethylene spacer is needed to leave the delicate electronic balance on the $\mathrm{Zr}$ center, required for ethylene com-

(24) Saldarriaga-Molina, C. H.; Clearfield, A.; Bernal, I. J. Organomet. Chem. 1974, 80, 79-90.

(25) For an overview of the role of MAO see, e.g.: Abel, E. W., Stone, F. G. A., Wilkinson, G., Eds. Comprehensive Organometallic Chemistry II; Pergamon: Oxford, U.K., 1995; Chapter 12, pp 1193-1208. 
Table 2. GPC Data for the Polymer Prepared from $4 a-c, f$ in Toluene and $\mathrm{FBS}^{a}$

\begin{tabular}{cccc}
\hline & & \multicolumn{2}{c}{$M_{\mathrm{n}}\left(10^{3} \mathrm{~g} \mathrm{~mol}^{-1}\right)\left(M_{\mathrm{w}} / M_{\mathrm{n}}\right)$} \\
\cline { 3 - 4 } entry & precatalyst & toluene & toluene/FC $72(1 / 1 \mathrm{v} / \mathrm{v})$ \\
\hline 1 & $\mathbf{4 a}^{b}$ & $119(2.7)$ & n.d. \\
2 & $\mathbf{4 a}^{c}$ & $21(8.1)$ & $79(3.2)$ \\
3 & $\mathbf{4 b}$ & $33(6.5)$ & $43(6.3)$ \\
4 & $\mathbf{4 c}$ & $69(2.7)$ & $99(4.3)$ \\
5 & $\mathbf{4} \mathbf{f}^{d}$ & $86(2.2)$ & $109(2.7)$
\end{tabular}

a Polymerization conditions: $[\mathrm{Zr}]=2.5 \times 10^{-4} \mathrm{~mol} \mathrm{~L}-1, \mathrm{Al} / \mathrm{Zr}$ $=500, t=30 \mathrm{~min}, p=1 \mathrm{bar}$, and $T=20{ }^{\circ} \mathrm{C}$ unless stated otherwise. ${ }^{b} t=15 \mathrm{~min} .{ }^{c}$ Polymerization conditions: $[\mathrm{Zr}]=5.8 \times$ $10^{-5} \mathrm{~mol} \mathrm{~L}-1, \mathrm{Al} / \mathrm{Zr}=400, t=30 \mathrm{~min}, p=6 \mathrm{bar}$, and $T=40^{\circ} \mathrm{C}$. In both cases the temperature of the reaction mixture rose to 80 ${ }^{\circ} \mathrm{C} .{ }^{d} t=5 \mathrm{~min}$.

plexation-insertion processes, intact. ${ }^{\text {a }}$ The effectiveness of a spacer is also exemplified by $4 \mathbf{c}$, where a methylene spacer is used between the Si atom and the pentafluorophenyl ring. It is noteworthy that, measured over the first $5 \mathrm{~min}, \mathbf{4 c}$ has an activity that is essentially identical with that of $\mathbf{4 f}$ (1196 and $1125 \mathrm{~kg}$ of PE ((mol of $\mathrm{Zr}$ ) bar h $)^{-1}$, respectively). For $\mathbf{4 d}$, in which all three methyl groups are replaced by $\mathrm{CH}_{2} \mathrm{C}_{6} \mathrm{~F}_{5}$, the activity was poor, probably because of the steric shielding of the metal center.

GPC analyses of the polymers showed that their number-averaged molecular weight $\left(M_{\mathrm{n}}\right)$ was reasonably high and that the molecular weight distributions were broad (Table 2). Due to the long polymerization times employed, the polydispersity indexes are higher than those predicted by Flory's most probable distribution $\left(M_{\mathrm{w}} / M_{\mathrm{n}}=2\right)$, but they are not exceptional for metallocene catalysts and can be explained by significant heterogenization of the reaction mixtures due to the precipitating polymer (both low solubility of the PE at the low reaction temperature and the relatively long reaction time play a role) and local temperature fluctuations. $^{28}$

The activities measured fit well within the range of activities reported in the literature for zirconocene precatalysts. ${ }^{26}$ The observation that the activities and molecular weight drop when more electron-withdrawing substituents are used parallels recent observations for pentafluorophenyl-substituted zirconocenes. ${ }^{27}$

The extremely broad molecular weight distribution obtained for $\mathbf{4 b}$ is remarkable, however, and closer inspection of the GPC data (Figure 5) indicated that in fact a bimodal distribution was obtained with the second molecular weight fraction located at higher average molecular weight $\left(M_{\mathrm{n}}=2 \times 10^{6}\right)$ relative to the PE obtained for $\mathbf{4 f}\left(M_{\mathrm{n}}=86 \times 10^{3}\right)$. The low-molecularweight fraction was found to be comparable to that of 4f. Although such a distribution could signify that the catalyst is not stable under the reaction conditions, resulting in the creation of multiple sites, ${ }^{29} \mathrm{NMR}$

(26) Möhring, P. C.; Coville, N. J. J. Organomet. Chem. 1994, 479, $1-29$

(27) Thornberry, M. P.; Reynolds, N. T.; Deck, P. A. Organometallics 2004, 23, 1333-1339.

(28) (a) Lahti, M.; Koivumaeki, J.; Seppaelae, J. V. Angew. Makromol. Chem. 1996, 236, 139-153. (b) Leino, R.; Luttikhedde, H. J. G.; Lehmus, P.; Wilén C.-E.; Sjöholm, R.; Lehtonen, A.; Seppälä, J. V.; Näsman, J. H. Macromolecules 1997, 30, 3477-3483. (c) Liu, J.; Støvneng, J. A.; Rytter, E. J. Polym. Sci. A: Polym. Chem. 2001, 39, $3566-3577$

(29) For example, one could envision nucleophilic attack by MAO or $\mathrm{AlMe}_{3}$, which is contained in MAO, on the Si atom replacing the $1 H, 1 H, 2 H, 2 H$-perfluoroalkyl group by a regular Me group.

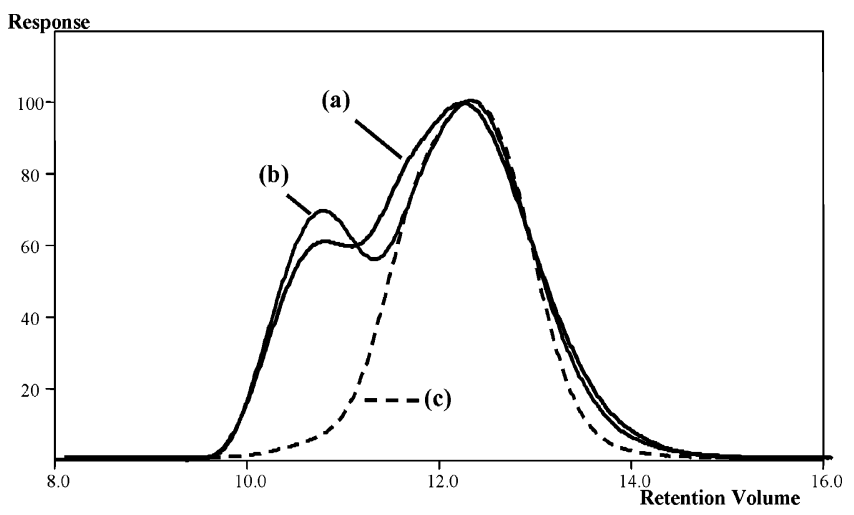

Figure 5. Differential pressure chromatograms for $\mathrm{PE}$ samples prepared from $\mathbf{4 b} / \mathrm{MAO}$ in toluene (a) and toluene/ FC 72 (b) compared to the PE obtained from 4f/MAO in toluene (c). Note that the low retention volume corresponds to a high-molecular-weight polymer.

investigations and pentane extractions of the quenched reaction mixtures indicate that the zirconocene moiety itself is unaffected when reacted with MAO (vide infra). Although this turned out to be hard to verify experimentally, a more likely explanation is that the hindered rotation around the $\mathrm{Zr}-\mathrm{Cp}$ axis, which was already observed for the parent dichloride $\mathbf{4 b}$ (vide supra), is sufficiently slow to afford species with different $k_{\mathrm{p}} / k_{\mathrm{t}}$ ratios $\left(k_{\mathrm{p}}=\right.$ rate constant for chain propagation, $k_{\mathrm{t}}=$ rate constant for chain termination). The steric crowding around the $\mathrm{Zr}$ center supplemented by the rigidity of the $-\mathrm{C}_{8} \mathrm{~F}_{19}$ tails ${ }^{30}$ may contribute to this phenomenon. Another possibility suggested by one of the reviewers of this paper, i.e. chain transfer to aluminum, appears to be less likely, as it generally leads to a lower molecular weight fraction and becomes important only at high $\mathrm{Al} / \mathrm{Zr}$ ratios. ${ }^{28 \mathrm{~b}, \mathrm{c}, 31}$ The GPC curves of the polymers obtained from the other catalysts in toluene were all unimodal.

A tempting explanation for the increased productivity of the fluorous precatalyst at longer polymerization times, which at this moment is purely speculative, is that the fluorous systems remain active after precipitation of the growing polymer chain. Precipitation normally results in liquid-to-solid mass transfer of ethylene followed by ethylene starvation and consequently chain termination. ${ }^{28 a}$ Occlusion of the active site in the precipitated PE may well become enthalpically less favorable for the fluorous complexes compared to nonfluorous precatalysts, resulting in continued availability and activity of the active site. ${ }^{32}$

Exploratory polymerization experiments with $4 \mathbf{a}-\mathbf{c , f}$ under FBS conditions (1:1 volumetric mixtures of toluene and FC-72 as well as of hexane and FC72) were undertaken to probe the possible effect of the fluorous

(30) Bunn, C. W.; Howells, E. R. Nature 1954, 174, 549.

(31) (a) Scollard, J. D.; McConville, D. H.; Vittal, J. J.; Payne N. C. J. Mol. Catal. A: Chem. 1998, 128, 201-214. (b) Britovsek, G. J. P.; Bruce, M.; Gibson, V. C.; Kimberley, B. S.; Maddox, P. J.; Mastroianni, S.; McTavish, S. J.; Redshaw, C.; Solan, G. A.; Strömberg, S.; White, A. J. P.; Williams, D. J. J. Am. Chem. Soc. 1999, 121, 8728.

(32) This would be another demonstration of fluorous biphasic separation behavior in the solid state caused by the inability of the fluorous metallocene fragment to enter into enthalpically favorable interactions with the $\mathrm{PE}$ that could otherwise compensate for the loss of intramolecular van der Waals interactions in the partly crystalline $\mathrm{PE}$. Related phase separation phenomena in the solid state have been observed in the X-ray structure of a fluorous Rh complex. ${ }^{20}$ 


\section{Scheme 3}

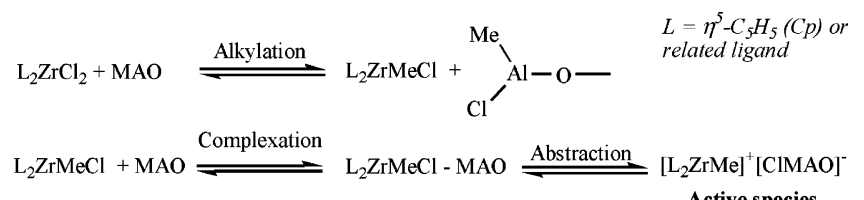

Active species

biphasic conditions on the activities. It was found that that the activities remained essentially unaffected, demonstrating that FC-72 is compatible with both MAO and the polymerization conditions and that the biphasic conditions did not result in problems with mass transport limitation. More importantly, under biphasic conditions the relative ranking of the activities of the fluorous complexes and nonfluorous 4 f that was observed in toluene was essentially reproduced, suggesting that partitioning of the active species into the fluorous phase is not yet significant at this level of fluorous character of the metallocene precatalysts. However, when the molecular weights of the resulting polymers are compared (Table 2), a general trend toward significantly higher average molecular weight is observed under the biphasic conditions.

In trying to rationalize the effect of replacing part of the toluene solvent by FC-72, it should be noted that the ionic catalyst system is essentially insoluble in the FC-72 phase. This could be easily concluded from experiments in pure FC-72 that resulted in poor activity $\left(<10 \mathrm{~kg}\right.$ of $\left.\mathrm{PE}((\mathrm{mol} \text { of } \mathrm{Zr}) \mathrm{bar} \mathrm{h})^{-1}\right)$ as well as visually observable poor solubility of the catalyst components. Although the solubility of ethylene in FC-72 is ca. 20\% higher than in toluene, ${ }^{33}$ this is of relatively low importance, as the polymerization reaction takes place predominantly in the toluene phase. Some surface activity cannot be ruled out in the case of the amphiphilic fluorous metallocene systems. However, by partial dissolution in the toluene layer (ca. 5 vol \%), the main effect of the perfluorocarbon solvent is to lower the dielectric constant of the toluene phase. The latter will promote tight ion pairing of the catalytic system, which in turn may be expected to suppress the rate of $\beta$-hydrogen transfer to the metal center. ${ }^{34}$ The observed increase in polymer molecular weight can thus be rationalized qualitatively.

When the shape of the GPC chromatogram for $\mathbf{4 b}$ was inspected, it was found that the higher molecular weight distribution gets more pronounced under the fluorous biphasic conditions (Figure 5), whereas the GPC curves for the other catalysts remained unimodal. Apparently the species with the highest $k_{\mathrm{p}} / k_{\mathrm{t}}$ ratio is favored by the presence of the fluorocarbon solvent.

Catalyst Analysis by ${ }^{1}$ H NMR Spectroscopy. The Lewis acid role of MAO in the formation of coordinately unsaturated cationic zirconocene alkyl species from the zirconocene dichloride precursor is now well established (Scheme 3); NMR spectroscopy has proven to be a useful technique for the characterization of these species, which are thought to be the actual catalysts for

(33) Derived from a plot of $\log x$ versus $\delta(x=$ mole fraction of ethylene, $\delta=$ Hildebrand parameter of the solvent): Jolley, J. E. Hildebrand, J. H. J. Am. Chem. Soc. 1958, 80, 1050-1054.

(34) (a) Stehling, U.; Diebold, J.; Kirsten, R.; Röll, W.; Brintizinger, H.-H. Organometallics 1994, 13, 964-970. (b) Pédeutour, J.-N.; Radhakrishnan, K.; Cramail, H.; Deffieux, A. Macromol. Rapid Commun. 2001, 22, 1095-1123. polymerization. ${ }^{34 b, 35}$ For the $\mathrm{Cp}_{2} \mathrm{ZrMe}_{2}-\mathrm{MAO}$ systems, these are the heterodinuclear $\left[\mathrm{Cp}_{2} \mathrm{Zr}(\mu-\mathrm{Me})_{2} \mathrm{AlMe}_{2}\right]^{+}[\mathrm{Me}-$ $\mathrm{MAO}]^{-}$and the unsymmetrical methyl-bridged complex $\left[\mathrm{Cp}_{2} \mathrm{ZrMe}\right]^{+}[\mathrm{Me}-\mathrm{MAO}]^{-}$ion pairs along with other intermediates (especially at low $\mathrm{Al} / \mathrm{Zr}$ ratio) such as the neutral $\left[\mathrm{Cp}_{2} \mathrm{ZrMe}_{2}\right][\mathrm{MAO}]$ adduct or the dimeric symmetric (on the cationic part) binuclear $\left[\mathrm{Cp}_{2} \mathrm{ZrMe}\right]_{2-}$ $(\mu-\mathrm{Me})^{+}[\mathrm{Me}-\mathrm{MAO}]^{-}$ion pair. ${ }^{35 \mathrm{a}}$

Solutions of precatalysts $4 \mathbf{a}-\mathbf{c}$ and MAO (benzene$d_{6}, \mathrm{Al} / \mathrm{Zr}=100$ ) were studied by ${ }^{1} \mathrm{H}$ NMR spectroscopy at ambient temperature (see Table 3 for NMR data and assignments). A remarkable feature for each experiment with precatalysts $4 \mathbf{a}-\mathbf{c}$ and MAO is the presence in the ${ }^{1} \mathrm{H}$ NMR spectrum of four broad signals for the monosubstituted-cyclopentadienyl group protons, which belong to the unsymmetrical methyl-bridged $\left[\left(\mathrm{CpSiMe}_{2} \mathrm{R}_{\mathrm{F}}\right)_{2}-\right.$ $\mathrm{ZrMe}]^{+}[\mathrm{X}-\mathrm{MAO}]^{-}\left(\mathrm{X}=\mathrm{Me}, \mathrm{Cl}, \mathrm{R}_{\mathrm{F}}=\mathrm{CH}_{2} \mathrm{CH}_{2} \mathrm{C}_{6} \mathrm{~F}_{13}\left(\mathbf{4} \mathbf{a}^{\prime}\right)\right.$, $\left.\mathrm{C}_{8} \mathrm{~F}_{17}\left(\mathbf{4} \mathbf{b}^{\prime}\right), \mathrm{CH}_{2} \mathrm{C}_{6} \mathrm{~F}_{5}\left(\mathbf{4} \mathbf{c}^{\prime}\right)\right)$ contact and separated ion pairs rather than to the heterodinuclear complex $\left[\left(\mathrm{CpSiMe} \mathrm{R}_{\mathrm{F}}\right)_{2} \mathrm{Zr}(\mu-\mathrm{Me})_{2} \mathrm{AlMe}_{2}\right]^{+}[\mathrm{X}-\mathrm{MAO}]^{-}(\mathrm{X}=\mathrm{Me}, \mathrm{Cl})$, for which only two $\mathrm{Cp} \mathrm{H}$ signals (symmetrical cationic part) would be expected. ${ }^{35 a}$ Nevertheless, the formation of the $\left[\left(\mathrm{CpSiMe}_{2} \mathrm{R}_{\mathrm{F}}\right)_{2} \mathrm{Zr}(\mu-\mathrm{Me})_{2} \mathrm{AlMe}_{2}\right]^{+}[\mathrm{X}-\mathrm{MAO}]^{-}(\mathrm{X}=$ $\mathrm{Me}, \mathrm{Cl}$ ) ion pair cannot be excluded, as its NMR signals could be non-resolved from the broad $\left[\left(\mathrm{CpSiMe}_{2} \mathrm{R}_{\mathrm{F}}\right)_{2^{-}}\right.$ $\mathrm{ZrMe}]^{+}[\mathrm{X}-\mathrm{MAO}]^{-}(\mathrm{X}=\mathrm{Me}, \mathrm{Cl})$ signals at ambient temperature. It is noteworthy that species $\mathbf{4}^{\prime}$ is observed in solution in equilibrium with the starting precatalyst 4 (in a 2:1 molar ratio) for complexes 4a,f, whereas $\mathbf{4}^{\prime}$ is the only species observed when $\mathbf{4 b , c}$ were treated with $\mathrm{MAO}$. At lower $\mathrm{Al} / \mathrm{Zr}$ ratio $(\mathrm{Al} / \mathrm{Zr}=20)$, a similar pattern for the Cp protons was observed, but at lower field, which is attributed to the unsymmetrical monomethylated $\left[\left(\mathrm{CpSiMe} \mathrm{R}_{\mathrm{F}}\right)_{2} \mathrm{Zr}(\mathrm{Me}) \mathrm{Cl}\right]\left(\mathrm{R}_{\mathrm{F}}=\mathrm{C}_{8} \mathrm{~F}_{17}\left(\mathbf{4} \mathbf{b}^{\prime \prime}\right), \mathrm{CH}_{2} \mathrm{C}_{6} \mathrm{~F}_{5}\right.$ $\left.\left(\mathbf{4} \mathbf{c}^{\prime \prime}\right)\right)$. These monomethyl complexes were observed along with unreacted precatalyst (3:1 ratio).

These observations are in accordance with previous observations for $\left[\mathrm{Cp}_{2} \mathrm{ZrCl}_{2}\right]-\mathrm{MAO}$ and $\mathbf{4 f}-\mathrm{MAO}^{35 a, e, 36}$ and also correlate, at least qualitatively, with recent work by Deck et al., ${ }^{37}$ where it was found that electronwithdrawing $\mathrm{C}_{6} \mathrm{~F}_{5}$ groups stabilize mononuclear cationic $\left[\left(\mathrm{CpC}_{6} \mathrm{~F}_{5}\right)_{2} \mathrm{ZrMe}\right]^{+}[\mathrm{X}-\mathrm{MAO}]^{-}$species. From these NMR studies no indications were obtained that precatalyst 4b behaves differently from the other precatalysts, leaving the origin of the bimodality of the polyethylene obtained with $\mathbf{4 b}$ unclear. Attempts to study solutions of complexes $\mathbf{4 a}-\mathbf{c}, \mathbf{f}$ and MAO at low temperatures were hampered by severe line broadening.

Most remarkably, hydrolysis of the fluorous species $4^{\prime}$ by aqueous alcoholic $\mathrm{HCl}$ regenerated the fluorous zirconocene dichlorides (characterized by both their ${ }^{1} \mathrm{H}$ and ${ }^{19} \mathrm{~F}$ NMR spectra) whereas hydrolysis of a $\mathbf{4 f}-\mathrm{MAO}$ solution led to decomposition of the catalyst, free $\mathrm{HCp}$ $\mathrm{SiMe}_{3}$ being the only product observed by ${ }^{1} \mathrm{H}$ NMR.

(35) (a) Babushkin, D. E.; Semikolenova, N. V.; Zakharov, V. A.; Talsi, E. P. Macromol. Chem. Phys. 2000, 201, 558. (b) Tritto, I. Donetti, R.; Sacchi, M. C.; Locatelli, P.; Zannoni, G. Macromolecules 1997, 30, 1247-1252. (c) Tritto, I.; Donetti, R.; Sacchi, M. C.; Locatelli P.; Zannoni, G. Macromolecules 1999, 32, 264-269. (d) Harlan, C. J. Bott, S. G.; Barron, A. R. J. Am. Chem. Soc. 1995, 117, 6465-6474. (e) Cam, D.; Giannini, U. Makromol. Chem. 1992, 193, 1049-1055.

(36) Nekhaeva, L. A.; Bondarenko, G. N.; Rykov, S. V.; Nekhaev, A. I.; Krentsel, B. A.; Mar'in, V. P.; Vyshinskaya, L. I.; Khrapova, I. M.; Polonskii, A. V.; Korneev, N. N. J. Organomet. Chem. 1991, 406, $139-146$. 3565. 
Moreover, pentane extraction of the quenched polymerization filtrate, from polymerization experiments with precatalysts $\mathbf{4 a}-\mathbf{d}$ and MAO, allowed, after removal of the solvent, recovery of the starting precatalyst. These results confirm the enhanced stability of the fluorous precatalyst. Also, they open up the possibility of (pre)catalyst recycling in metallocene polymerization even though there might not be a practical need for it, given the low catalyst loadings of industrial metallocene-based olefin polymerization processes.

\section{Conclusions}

In conclusion, four new crystalline, highly stable zirconocene(IV) dichlorides, substituted with one fluorous silyl group per cyclopentadienyl ring, have been prepared. They are hydrocarbon soluble and even moderately soluble in perfluorocarbons (PFC's). Three of these four fluorous complexes $(\mathbf{4 a}-\mathbf{c})$ form active ethylene polymerization catalysts when reacted with an excess of methylaluminoxane (MAO, $\mathrm{Al} / \mathrm{Zr}=500)$ in pure toluene but also in fluorous biphasic solvent systems (e.g. toluene/perfluorohexanes). The most important observation is that these fluorous zirconocene systems display increased robustness and consequently increased productivity over prolonged polymerization times in comparison to the nonfluorous reference system $\left[\mathrm{Zr}\left(\eta^{5}-\mathrm{C}_{5} \mathrm{H}_{4} \mathrm{SiMe}_{3}\right)_{2} \mathrm{Cl}_{2}\right]$ (4f). This phenomenon may well be related to phase segregation of the fluorous metallocene moiety from the polyethylene matrix and will be investigated further in future studies.

The more electron-withdrawing fluorinated hydrocarbyl substituents on the cyclopentadienyl ligand result in lower initial polymerization activity and a decreased molecular weight of the polyethylene obtained, probably as a result of a decreased propagation rate. Remarkably, fluorous biphasic conditions during the polymerization reaction in general result in higher polymer molecular weight. This phenomenon was even observed for nonfluorous $\mathbf{4 f}$ and is most likely caused by a suppression of the rate of $\beta-\mathrm{H}$ transfer to the metal center in these relatively nonpolar solvent combinations. For the most fluorous zirconocene complex bearing two $-\mathrm{SiMe}_{2} \mathrm{C}_{8} \mathrm{~F}_{17}$ tails (4b) a polyethylene with a bimodal molecular weight distribution was obtained, the higher molecular weight part of which became more pronounced under fluorous biphasic conditions. ${ }^{1} \mathrm{H}$ NMR experiments on benzene- $d_{6}$ solution of the precatalysts and $\mathrm{MAO}(\mathrm{Al} /$ $\mathrm{Zr}=100$ ) have shown the formation of unsymmetrical $\left[\left(\mathrm{CpSiMe}_{2} \mathrm{R}_{\mathrm{F}}\right)_{2} \mathrm{ZrMe}\right]^{+}[\mathrm{Me}-\mathrm{MAO}]^{-}$ion pairs rather than the heterodinuclear $\left[\left(\mathrm{CpSiMe}{ }_{2} \mathrm{R}_{\mathrm{F}}\right)_{2} \mathrm{Zr}(\mu-\mathrm{Me})_{2} \mathrm{AlMe}_{2}\right]^{+}$. $[\mathrm{MeMAO}]^{-}$ion pairs as the predominant species.

\section{Experimental Section}

General Considerations. All experiments were carried out under dry nitrogen using standard Schlenk techniques. Solvents were dried and distilled prior to use following literature procedures. Elemental analyses were performed by Dornis und Kolbe, Mikroanalytisches Laboratorium (Mülheim, Germany). ${ }^{1} \mathrm{H}(300.1 \mathrm{MHz}),{ }^{13} \mathrm{C}(75.5 \mathrm{MHz}),{ }^{29} \mathrm{Si}(59.6 \mathrm{MHz})$, and ${ }^{19} \mathrm{~F}(282.4$ $\mathrm{MHz}$ ) NMR spectra were recorded on a Varian INOVA 300 spectrometer at $25{ }^{\circ} \mathrm{C}$, unless otherwise stated, and were referenced internally $\left({ }^{1} \mathrm{H},{ }^{13} \mathrm{C}\right)$ to residual solvent resonances or externally (to $\mathrm{SiMe}_{4}$ for ${ }^{29} \mathrm{Si}$ and $\mathrm{CFCl}_{3}$ for ${ }^{19} \mathrm{~F}$ ). Melting points were measured in sealed capillaries on a Tottoli apparatus and are uncorrected. Mass spectra (nanoES-Q-TOFMS) were performed by C. Versluis (Department of Biomolecular Mass Spectrometry, Utrecht University, NL) using a Micromass Q-Tof hybrid tandem mass spectrometer and the MassLynx software, version 3.0. GPC analyses (against polystyrene standard in 1,2-dichlorobenzene at $140{ }^{\circ} \mathrm{C}$ ) were performed by Rapra Technology Ltd (U.K.). Cyclopentadiene was obtained by cracking of dicyclopentadiene and distilled prior to use, $\mathrm{CpLi}$ was prepared by directly cracking dicyclopentadiene over a solution of $\mathrm{LiBu}^{\mathrm{n}}\left(1.6 \mathrm{~mol} \mathrm{~L}^{-1}\right.$ in hexane). Chlorodimethyl $(1 H, 1 H, 2 H, 2 H$-perfluorooctyl)silane was prepared by following reported methods. ${ }^{11,38}$ All other reagents were purchased from commercial sources and used without further purification. For all the polymerization tests, a $10 \mathrm{wt}$ $\%$ solution of MAO in toluene from WITCO $\left(d_{20}=0.885\right.$, total $\mathrm{Al}$ content $4.8 \mathrm{wt} \%)$ and ethylene $(3.0,>99.9 \%$, Hoek Loos) were used as received.

Dimethyl(perfluoroctyl)silane (1b). $\mathrm{LiBu}^{\mathrm{n}}(80 \mathrm{~mL}$ of a $1.6 \mathrm{~mol} \mathrm{~L}^{-1}$ solution in hexane, $\left.50 \mathrm{mmol}\right)$ and hexane $(90 \mathrm{~mL})$ were added dropwise over a period of $4.5 \mathrm{~h}$ to a solution of $\mathrm{C}_{8} \mathrm{~F}_{17} \mathrm{I}(26.52 \mathrm{~g}, 48.6 \mathrm{mmol})$ and $\mathrm{HSiMe}_{2} \mathrm{Cl}(6.8 \mathrm{~mL}, 85 \mathrm{mmol})$ in $\mathrm{Et}_{2} \mathrm{O}(150 \mathrm{~mL})$ at $-78^{\circ} \mathrm{C}$. After the mixture was warmed to ambient temperature, a white suspension had formed, and water $(50 \mathrm{~mL})$ and $\mathrm{Et}_{2} \mathrm{O}(150 \mathrm{~mL})$ were added. The layers were separated, and the ethereal layer was washed with brine (30 $\mathrm{mL}$ ) and dried on $\mathrm{MgSO}_{4}$. Removal of the volatiles using a rotary evaporator gave a yellow oil $(19.8 \mathrm{~g})$. Fractional distillation (11 mbar, $57-59{ }^{\circ} \mathrm{C}$ ) using a $10 \mathrm{~cm}$ Vigreux column gave $\mathrm{HSiMe}_{2} \mathrm{C}_{8} \mathrm{~F}_{17}(\mathbf{1 b})$ as a colorless liquid $(10.14 \mathrm{~g}, 44 \%)$, which according to ${ }^{19} \mathrm{~F}$ NMR contained approximately $5 \% \mathrm{C}_{8} \mathrm{~F}_{17} \mathrm{I} .{ }^{1} \mathrm{H}$ $\operatorname{NMR}\left(\delta, \mathrm{CDCl}_{3}\right): 0.38\left(\mathrm{~d}, 6 \mathrm{H},{ }^{3} J_{\mathrm{H}, \mathrm{H}}=4 \mathrm{~Hz}, \mathrm{SiMe}_{2}\right), 4.24(\mathrm{br}$, $1 \mathrm{H}, \mathrm{Si}-\mathrm{H}),{ }^{13} \mathrm{C}\left\{{ }^{19} \mathrm{~F}\right\} \operatorname{NMR}\left(\delta, \mathrm{CDCl}_{3}\right):-7.9\left(\mathrm{q},{ }^{1} J_{\mathrm{H}, \mathrm{C}}=125\right.$ $\left.\mathrm{Hz}, \mathrm{SiMe}_{2}\right), 108.6,110.5,111.0,111.7,117.4\left(\mathrm{t},{ }^{2} J_{\mathrm{F}, \mathrm{C}}=19 \mathrm{~Hz}\right.$, $\left.\mathrm{CF}_{3}\right), 122.7\left(\mathrm{CF}_{2} \mathrm{Si}\right) .{ }^{19} \mathrm{~F} \mathrm{NMR}\left(\delta, \mathrm{CDCl}_{3}\right):-81.9\left(\mathrm{t}, 3 \mathrm{~F},{ }^{4} J_{\mathrm{F}, \mathrm{F}}=\right.$ $9 \mathrm{~Hz}, \mathrm{CF}_{3}$ ), -120.8 (br s, $2 \mathrm{~F}, \mathrm{~F}^{2}$ ), -122.6 (br s, $2 \mathrm{~F}, \mathrm{~F}^{3}$ ), -122.8 (br s, $4 \mathrm{~F}, \mathrm{~F}^{4}$ and $\left.\mathrm{F}^{5}\right),-123.6\left(\mathrm{br} \mathrm{s}, 2 \mathrm{~F}, \mathrm{~F}^{6}\right),-127.1(\mathrm{br} \mathrm{s}, 2 \mathrm{~F}$, $\left.\mathrm{F}^{7}\right),-127.6\left(\mathrm{~d}, 2 \mathrm{~F},{ }^{3} \mathrm{~J}_{\mathrm{H}, \mathrm{F}}=12 \mathrm{~Hz}, \mathrm{~F}^{1}\right) .{ }^{29} \mathrm{Si}\left\{{ }^{1} \mathrm{H}\right\} \operatorname{NMR}\left(\delta, \mathrm{CDCl}_{3}\right)$ : $-8.3\left(\mathrm{tt},{ }^{2} J_{\mathrm{F}, \mathrm{Si}}=30 \mathrm{~Hz},{ }^{3} \boldsymbol{J}_{\mathrm{F}, \mathrm{Si}}=6 \mathrm{~Hz}\right)$

(2,3,4,5,6-Pentafluorobenzyl)dimethylsilane (1c). A solution of $\mathrm{BrCH}_{2} \mathrm{C}_{6} \mathrm{~F}_{5}$ (10.55 g, $\left.40.4 \mathrm{mmol}\right)$ and $\mathrm{HSiMe}_{2} \mathrm{Cl}$ (4.11 $\mathrm{g}, 43.4 \mathrm{mmol})$ in $\mathrm{Et}_{2} \mathrm{O}(150 \mathrm{~mL})$ was added over a period of 4 $\mathrm{h}$ to magnesium turnings ( $2.65 \mathrm{~g}, 109 \mathrm{mmol})$ on suspension in $\mathrm{Et}_{2} \mathrm{O}(50 \mathrm{~mL})$. The greenish suspension was stirred at ambient temperature for ca. $15 \mathrm{~h}$ and quenched with $\mathrm{H}_{2} \mathrm{O}(50 \mathrm{~mL})$. The aqueous layers was extracted with $\mathrm{Et}_{2} \mathrm{O}(3 \times 50 \mathrm{~mL})$, the organic layers were washed with brine $(50 \mathrm{~mL})$ and dried over $\mathrm{MgSO}_{4}$, and solvent was removed in vacuo to yield the desired product as a colorless oil $(8.66 \mathrm{~g}, 89 \%)$. ${ }^{1} \mathrm{H} \mathrm{NMR}\left(\delta, \mathrm{CDCl}_{3}\right)$ : $0.17\left(\mathrm{~m}, 6 \mathrm{H}, \mathrm{SiMe}_{2}\right), 2.20\left(\mathrm{~m}, 2 \mathrm{H}, \mathrm{CH}_{2}\right), 4.01(\mathrm{~m}, 1 \mathrm{H}, \mathrm{H}-\mathrm{Si})$. ${ }^{13} \mathrm{C}\left\{{ }^{1} \mathrm{H}\right\} \operatorname{NMR}\left(\delta, \mathrm{CDCl}_{3}\right):-4.6\left(\mathrm{SiMe}_{2}\right), 10.1\left(\mathrm{CH}_{2}\right), 114.2(\mathrm{t}$, ${ }^{2} J_{\mathrm{F}, \mathrm{C}}=240 \mathrm{~Hz}$, ipso- $\left.\mathrm{C}_{6} \mathrm{~F}_{5}\right), 137.8\left(\mathrm{dm},{ }^{1} J_{\mathrm{F}, \mathrm{C}}=280 \mathrm{~Hz}, m-\mathrm{C}_{6} \mathrm{~F}_{5}\right)$, $138.4\left(\mathrm{dm},{ }^{1} J_{\mathrm{F}, \mathrm{C}}=240 \mathrm{~Hz}, p-\mathrm{C}_{6} \mathrm{~F}_{5}\right), 144.4\left(\mathrm{dm},{ }^{1} J_{\mathrm{F}, \mathrm{C}}=250 \mathrm{~Hz}\right.$, $\left.o-\mathrm{C}_{6} \mathrm{~F}_{5}\right) \cdot{ }^{19} \mathrm{~F}$ NMR $\left(\delta, \mathrm{CDCl}_{3}\right):-144.5\left(\mathrm{dd}, 2 \mathrm{~F},{ }^{3} \boldsymbol{J}_{\mathrm{F}, \mathrm{F}}=23 \mathrm{~Hz}\right.$ $\left.{ }^{4} J_{\mathrm{F}, \mathrm{F}}=8 \mathrm{~Hz}, o-\mathrm{C}_{6} \mathrm{~F}_{5}\right),-161.9\left(\mathrm{dd}, 2 \mathrm{~F},{ }^{3} J_{\mathrm{F}, \mathrm{F}}=22 \mathrm{~Hz}, p-\mathrm{C}_{6} \mathrm{~F}_{5}\right)$, $-164.5\left(\mathrm{dd}, 2 \mathrm{~F},{ }^{3} J_{\mathrm{F}, \mathrm{F}}=21 \mathrm{~Hz}{ }^{4} J_{\mathrm{F}, \mathrm{F}}=9 \mathrm{~Hz}, m-\mathrm{C}_{6} \mathrm{~F}_{5}\right) .{ }^{29} \mathrm{Si}\left\{{ }^{1} \mathrm{H}\right\}$ $\operatorname{NMR}\left(\delta, \mathrm{CDCl}_{3}\right):-11.5$ (s). Anal. Calcd for $\mathrm{C}_{9} \mathrm{H}_{9} \mathrm{~F}_{5} \mathrm{Si}: \mathrm{C}, 44.99$; H, 3.78. Found: C, 45.16; H, 3.86.

Tris(2,3,4,5,6-pentafluorobenzyl)silane (1d). A solution of $\mathrm{BrCH}_{2} \mathrm{C}_{6} \mathrm{~F}_{5}(9.74 \mathrm{~g}, 37.3 \mathrm{mmol})$ and $\mathrm{HSiCl}_{3}(1.2 \mathrm{~mL}, 12$ $\mathrm{mmol})$ in $\mathrm{Et}_{2} \mathrm{O}(150 \mathrm{~mL})$ was added over a period of $4.5 \mathrm{~h}$ to magnesium turnings $(2.20 \mathrm{~g}, 90 \mathrm{mmol})$ in suspension in $\mathrm{Et}_{2} \mathrm{O}$ $(100 \mathrm{~mL})$. The greenish suspension was refluxed for $1 \mathrm{~h}$ and then quenched with $\mathrm{H}_{2} \mathrm{O}(50 \mathrm{~mL})$. The aqueous layers was extracted with $\mathrm{Et}_{2} \mathrm{O}(3 \times 50 \mathrm{~mL})$, and the organic layers were washed with brine $(50 \mathrm{~mL})$, dried over $\mathrm{MgSO}_{4}$, and concentrated to dryness in vacuo to yield the title compound as a yellowish solid $(5.83 \mathrm{~g}, 86 \%) .{ }^{1} \mathrm{H} \mathrm{NMR}\left(\delta, \mathrm{CDCl}_{3}\right): 2.30(\mathrm{~m}$, $\left.6 \mathrm{H}, \mathrm{CH}_{2}\right), 4.06(\mathrm{~m}, 1 \mathrm{H}, \mathrm{Si}-\mathrm{H}) .{ }^{13} \mathrm{C}\left\{{ }^{1} \mathrm{H}\right\} \mathrm{NMR}\left(\delta, \mathrm{CDCl}_{3}\right): 7.3$

(38) Ameduri, B.; Boutevin, B.; Nouiri, M.; Talbi, M. J. Fluorine Chem. 1995, 74, 191-197. 
$\left(\mathrm{CH}_{2}\right), 111.4\left(\right.$ ipso- $\left.\mathrm{C}_{6} \mathrm{~F}_{5}\right), 137.8\left(\mathrm{dm},{ }^{1} J_{\mathrm{F}, \mathrm{C}}=250 \mathrm{~Hz}, m-\mathrm{C}_{6} \mathrm{~F}_{5}\right)$, $139.3\left(\mathrm{dm},{ }^{1} J_{\mathrm{F}, \mathrm{C}}=250 \mathrm{~Hz}, p-\mathrm{C}_{6} \mathrm{~F}_{5}\right), 144.5\left(\mathrm{dm},{ }^{1} J_{\mathrm{F}, \mathrm{C}}=250 \mathrm{~Hz}\right.$, $\left.o-\mathrm{C}_{6} \mathrm{~F}_{5}\right),{ }^{19} \mathrm{~F}$ NMR $\left(\delta, \mathrm{CDCl}_{3}\right):-143.2\left(\mathrm{dd}, 2 \mathrm{~F},{ }^{3} \boldsymbol{J}_{\mathrm{F}, \mathrm{F}}=21 \mathrm{~Hz}\right.$ $\left.{ }^{4} J_{\mathrm{F}, \mathrm{F}}=6 \mathrm{~Hz}, o-\mathrm{C}_{6} \mathrm{~F}_{5}\right),-158.5\left(\mathrm{t}, 1 \mathrm{~F},{ }^{3} J_{\mathrm{F}, \mathrm{F}}=21 \mathrm{~Hz}, p-\mathrm{C}_{6} \mathrm{~F}_{5}\right)$, $-162.5\left(\mathrm{dt}, 2 \mathrm{~F},{ }^{3} \boldsymbol{J}_{\mathrm{F}, \mathrm{F}}=21 \mathrm{~Hz}{ }^{4} \boldsymbol{J}_{\mathrm{F}, \mathrm{F}}=6 \mathrm{~Hz}, m-\mathrm{C}_{6} \mathrm{~F}_{5}\right) .{ }^{29} \mathrm{Si}\left\{{ }^{1} \mathrm{H}\right\}$ $\operatorname{NMR}\left(\delta, \mathrm{CDCl}_{3}\right)$ : $-6.4(\mathrm{~s})$. Anal. Calcd for $\mathrm{C}_{21} \mathrm{H}_{7} \mathrm{~F}_{15} \mathrm{Si}: \mathrm{C}, 44.07$; H, 1.23. Found: C, 43.94; H, 1.30 .

Bromodimethyl(perfluorooctyl)silane (2b). A mixture of $\mathrm{HSiMe}_{2} \mathrm{C}_{8} \mathrm{~F}_{17}(\mathbf{1 b} ; 7.56 \mathrm{~g}, 15.8 \mathrm{mmol})$ and $\mathrm{Br}_{2}(3.2 \mathrm{~mL}, 62$ mmol) in $\mathrm{CCl}_{4}(25 \mathrm{~mL})$ was stirred for $18 \mathrm{~h}$ at $60{ }^{\circ} \mathrm{C}$ in a Schlenk flask which had been fitted with a condenser and a $\mathrm{CaCl}_{2}$ tube. After removal of the volatiles in vacuo, the resulting liquid was flash-distilled to yield the title compound as a pale pink liquid $(8.35 \mathrm{~g}, 95 \%) .{ }^{19} \mathrm{~F}$ NMR spectroscopy showed that it contained approximately $5 \% \mathrm{C}_{8} \mathrm{~F}_{17} \mathrm{I}$ and was used as such. ${ }^{1} \mathrm{H}$ NMR $\left(\delta, \mathrm{CDCl}_{3}\right): 0.84(\mathrm{~s}) .{ }^{13} \mathrm{C}\left\{{ }^{19} \mathrm{~F}\right\} \operatorname{NMR}(\delta$, $\left.\mathrm{CDCl}_{3}\right):-0.1\left(\mathrm{q},{ }^{1} J_{\mathrm{H}, \mathrm{C}}=124 \mathrm{~Hz}, \mathrm{SiMe}_{2}\right), 108.6$ (partly resolved $\left.\mathrm{q}, J_{\mathrm{F}, \mathrm{C}}=12 \mathrm{~Hz}\right), 110.4,111.0(\mathrm{~s}, 2 \mathrm{C}), 111.6,113.0,117.4(\mathrm{t}$, $\left.{ }^{2} J_{\mathrm{F}, \mathrm{C}}=21 \mathrm{~Hz}, \mathrm{CF}_{3}\right), 119.3\left(\mathrm{CF}_{2} \mathrm{Si}\right) .{ }^{19} \mathrm{~F} \mathrm{NMR}\left(\delta, \mathrm{CDCl}_{3}\right):-82.0$ (t, $3 \mathrm{~F},{ }^{4} J_{\mathrm{F}, \mathrm{F}}=9 \mathrm{~Hz}, \mathrm{CF}_{3}$ ), -118.8 (br s, $\left.2 \mathrm{~F}, \mathrm{~F}^{1}\right),-122.5$ (br s, $\left.2 \mathrm{~F}, \mathrm{~F}^{3}\right),-122.9\left(\mathrm{br} \mathrm{s}, 4 \mathrm{~F}, \mathrm{~F}^{4}\right.$ and $\left.\mathrm{F}^{5}\right),-123.7\left(\mathrm{br} \mathrm{s}, 2 \mathrm{~F}, \mathrm{~F}^{6}\right)$, $-127.2\left(\mathrm{~m}, 4 \mathrm{~F}, \mathrm{~F}^{1}\right.$ and $\left.\mathrm{F}^{7}\right) .{ }^{29} \mathrm{Si}\left\{{ }^{1} \mathrm{H}\right\} \mathrm{NMR}\left(\delta, \mathrm{CDCl}_{3}\right): 17.7(\mathrm{t}$, $\left.{ }^{2} J_{\mathrm{F}, \mathrm{Si}}=35 \mathrm{~Hz}\right)$

Bromo(2,3,4,5,6-pentafluorobenzyl)dimethylsilane (2c). A solution of $\mathrm{HSiMe}_{2}\left(\mathrm{CH}_{2} \mathrm{C}_{6} \mathrm{~F}_{5}\right)(\mathbf{1 c} ; 8.66 \mathrm{~g}, 36.0 \mathrm{mmol})$ and $\mathrm{Br}_{2}(3.6 \mathrm{~mL}, 70 \mathrm{mmol})$ in pentane $(30 \mathrm{~mL})$ was stirred at ambient temperature for a period of 3 days. The dark brown solution was concentrated to dryness to afford the desired product as a clear orange oil $(11.36 \mathrm{~g}, 98 \%)$. ${ }^{1} \mathrm{H}$ NMR $(\delta$, $\left.\mathrm{CDCl}_{3}\right): 0.62\left(\mathrm{~m}, 6 \mathrm{H}, \mathrm{SiMe}_{2}\right), 2.53\left(\mathrm{t}, 2 \mathrm{H},{ }^{4} J_{\mathrm{F}, \mathrm{H}}=2 \mathrm{~Hz}, \mathrm{CH}_{2}\right)$. ${ }^{13} \mathrm{C}\left\{{ }^{1} \mathrm{H}\right\} \operatorname{NMR}\left(\delta, \mathrm{CDCl}_{3}\right): 2.5\left(\mathrm{SiMe}_{2}\right), 15.5\left(\mathrm{CH}_{2}\right), 135.3,140.2$, 142.0, and 144.4 $\left(C_{6} \mathrm{~F}_{5}\right)$. Anal. Calcd for $\mathrm{C}_{9} \mathrm{H}_{8} \mathrm{BrF}_{5} \mathrm{Si}$ : C, 33.87; H, 2.53. Found (duplicate analysis): C, 34.35; H, 2.66.

Bromotris(2,3,4,5,6-pentafluorobenzyl)silane (2d). A solution of $\mathrm{HSi}\left(\mathrm{CH}_{2} \mathrm{C}_{6} \mathrm{~F}_{5}\right)_{3}(\mathbf{1 c} ; 6.97 \mathrm{~g}, 12.2 \mathrm{mmol})$ and $\mathrm{Br}_{2}(1.2$ $\mathrm{mL}, 23.3 \mathrm{mmol})$ in hexane $(40 \mathrm{~mL})$ was stirred at ambient temperature for a period of 6 days. The dark brown solution was concentrated to dryness in vacuo and the brown sticky solid extracted with pentane $(50 \mathrm{~mL})$; crystallization at -20 ${ }^{\circ} \mathrm{C}$ gave the title compound as beige microcrystals $(6.0 \mathrm{~g}, 76 \%$, first crop). ${ }^{1} \mathrm{H}$ NMR $\left(\delta, \mathrm{CDCl}_{3}\right): 2.65\left(\mathrm{~m}, 6 \mathrm{H}, \mathrm{CH}_{2}\right) .{ }^{13} \mathrm{C}\left\{{ }^{19} \mathrm{~F}\right\}$ $\operatorname{NMR}\left(\delta, \mathrm{CDCl}_{3}\right): 12.8\left(\mathrm{t},{ }^{1} J_{\mathrm{C}, \mathrm{H}}=127 \mathrm{~Hz}, \mathrm{CH}_{2}\right), 109.8\left(\mathrm{t},{ }^{2} J_{\mathrm{C}, \mathrm{H}}\right.$ $=7 \mathrm{~Hz}$, ipso- $\left.\mathrm{C}_{6} \mathrm{~F}_{5}\right), 138.0\left(\mathrm{~m}, m-\mathrm{C}_{6} \mathrm{~F}_{5}\right), 139.7\left(\mathrm{~m}, p-\mathrm{C}_{6} \mathrm{~F}_{5}\right), 144.6$ $\left(\mathrm{m}, o-\mathrm{C}_{6} \mathrm{~F}_{5}\right),{ }^{19} \mathrm{~F} \operatorname{NMR}\left(\delta, \mathrm{CDCl}_{3}\right):-141.9\left(\mathrm{dd}, 2 \mathrm{~F},{ }^{3} J_{\mathrm{F}, \mathrm{F}}=21\right.$ $\left.\mathrm{Hz},{ }^{4} J_{\mathrm{F}, \mathrm{F}}=8 \mathrm{~Hz}, o-\mathrm{C}_{6} \mathrm{~F}_{5}\right),-157.2\left(\mathrm{t}, 1 \mathrm{~F},{ }^{3} J_{\mathrm{F}, \mathrm{F}}=21 \mathrm{~Hz}, p-\mathrm{C}_{6} \mathrm{~F}_{5}\right)$, $-162.1\left(\mathrm{dt}, 2 \mathrm{~F},{ }^{3} \boldsymbol{J}_{\mathrm{F}, \mathrm{F}}=21 \mathrm{~Hz},{ }^{4} \boldsymbol{J}_{\mathrm{F}, \mathrm{F}}=8 \mathrm{~Hz}, m-\mathrm{C}_{6} \mathrm{~F}_{5}\right) .{ }^{29} \mathrm{Si}\left\{{ }^{1} \mathrm{H}\right\}$ NMR $\left(\delta, \mathrm{CDCl}_{3}\right)$ : 19.2 (s). Anal. Calcd for $\mathrm{C}_{21} \mathrm{H}_{6} \mathrm{BrF}_{15} \mathrm{Si}$ : C, 38.73; H, 0.93. Found: C, 39.11; H, 1.01.

[Dimethyl $(1 H, 1 H, 2 H, 2 H$-perfluoroctyl)silyl]cyclopentadiene (3a). Freshly distilled cyclopentadiene $(2.40 \mathrm{~mL}, 29.1$ mmol) was added to a cooled $\left(0{ }^{\circ} \mathrm{C}\right)$ solution of $\mathrm{LiBu}^{\mathrm{n}}(50 \mathrm{~mL}$ of a $1.6 \mathrm{~mol} \mathrm{~L}^{-1}$ solution in hexane, $\left.31.3 \mathrm{mmol}\right)$ in hexane (100 $\mathrm{mL}$ ). The reaction mixture was stirred for $3 \mathrm{~h}$ at ambient temperature. After removal of the solvent in vacuo, the solid was washed with pentane $(3 \times 50 \mathrm{~mL})$ and dried under vacuum. The $\mathrm{Li}\left[\mathrm{C}_{5} \mathrm{H}_{5}\right]$ was dissolved in $\mathrm{THF}(100 \mathrm{~mL})$ at -78 ${ }^{\circ} \mathrm{C}$ and the solution added dropwise by cannula over $0.5 \mathrm{~h}$ to a solution of $\mathrm{C}_{6} \mathrm{~F}_{13} \mathrm{C}_{2} \mathrm{H}_{4} \mathrm{SiMe}_{2} \mathrm{Cl}(\mathbf{2 a} ; 13 \mathrm{~g}, 29.5 \mathrm{mmol})$ in $\mathrm{THF}$ $(100 \mathrm{~mL})$ at $0{ }^{\circ} \mathrm{C}$. The reaction mixture was stirred overnight at ambient temperature. Volatiles were removed in vacuo, the solid was extracted with pentane $(100 \mathrm{~mL})$, and the filtrate was concentrated to dryness in vacuo to give an orange oil. The pure title compound was obtained as a colorless oil (10.94 $\mathrm{g}, 80 \%$ ) by distillation $\left(75-80{ }^{\circ} \mathrm{C}\right.$ at $\left.510^{-1} \mathrm{mbar}\right)$. The ${ }^{1} \mathrm{H}$ NMR spectrum is complicated by the presence of 1- and 2-silyl isomers (minor) next to the 5-silyl isomer (major, ca. $80 \%$ ). ${ }^{1} \mathrm{H}$ $\operatorname{NMR}\left(\delta, \mathrm{CDCl}_{3}\right): 0.03\left(\mathrm{~s}, \mathrm{SiMe}_{2}, 5-\left(\mathrm{R}_{\mathrm{F}} \mathrm{SiMe}_{2}\right) \mathrm{C}_{5} \mathrm{H}_{5}\right.$ isomer $), 0.21$ (s, $\mathrm{SiMe} 2$, 1- and 2-( $\left.\mathrm{R}_{\mathrm{F}} \mathrm{SiMe}_{2}\right) \mathrm{C}_{5} \mathrm{H}_{5}$ isomers), 0.68 (m, $\mathrm{CH}_{2}-\mathrm{Si}$, 5- $\left(\mathrm{R}_{\mathrm{F}} \mathrm{SiMe}_{2}\right) \mathrm{C}_{5} \mathrm{H}_{5}$ isomer $), 0.88\left(\mathrm{~m}, \mathrm{CH}_{2}-\mathrm{Si}, 1-\right.$ and $2-\left(\mathrm{R}_{\mathrm{F}} \mathrm{SiMe}_{2}\right)-$ $\mathrm{C}_{5} \mathrm{H}_{5}$ isomers), 1.98 (m, $\mathrm{CH}_{2}-\mathrm{CF}_{2}$, all isomers), $3.04\left(\mathrm{~m}, \mathrm{CH}_{2}\right.$ of 1- and 2-( $\left.\left.\mathrm{R}_{\mathrm{F}} \mathrm{SiMe}_{2}\right) \mathrm{C}_{5} H_{5}\right), 3.40\left(\mathrm{~m}, \mathrm{CH}_{2}\right.$ of $5-\left(\mathrm{R}_{\mathrm{F}} \mathrm{SiMe}_{2}\right) \mathrm{C}_{5} \mathrm{H}_{5}$ isomer), 6.63 and $6.53\left(\mathrm{~m}, \alpha-+\beta-H 5-\left(\mathrm{R}_{\mathrm{F}} \mathrm{SiMe}_{2}\right) \mathrm{C}_{5} H_{5}\right.$ isomer $)$, 6.87 and $6.71\left(\mathrm{~m}, \alpha-+\beta-H\right.$ of 1 - and $2-\left(\mathrm{R}_{\mathrm{F}} \mathrm{SiMe}_{2}\right) \mathrm{C}_{5} H_{5}$ isomers $)$. Anal. Calcd for $\mathrm{C}_{15} \mathrm{H}_{15} \mathrm{~F}_{13} \mathrm{Si}$ : C, 38.30; H, 3.19; F, 52.55; $\mathrm{Si}$, 5.96. Found: C, 38.08; H, 3.29; F, 52.74; Si, 5.81.

[Dimethyl(perfluorooctyl)silyl]cyclopentadiene (3b). A solution of CpLi $(0.93 \mathrm{~g}, 12.9 \mathrm{mmol})$ in THF $(50 \mathrm{~mL})$ was added dropwise to a stirred solution of $\mathrm{BrSiMe}_{2} \mathrm{C}_{8} \mathrm{~F}_{17}(\mathbf{2} \mathbf{b} ; 7.32$ $\mathrm{g}, 13.1 \mathrm{mmol})$ in $\mathrm{THF}(50 \mathrm{~mL})$ at $0{ }^{\circ} \mathrm{C}$. The brownish solution was stirred for $1 \mathrm{~h}$ at ambient temperature and quenched with water $(200 \mathrm{~mL})$. The aqueous layer was extracted with pentane $(200 \mathrm{~mL})$, and the organic layer was washed with water $(2 \times$ $50 \mathrm{~mL})$ and brine $(30 \mathrm{~mL})$ and dried over $\mathrm{MgSO}_{4}$. Solvent was removed in vacuo using a rotary evaporator. The resulting liquid was Kugelrohr-distilled $\left(10^{-2} \mathrm{mbar}, 100^{\circ} \mathrm{C}\right)$ to yield the title compound as a clear yellow liquid $(5.00 \mathrm{~g}, 70 \%) .{ }^{1} \mathrm{H}$ and ${ }^{19} \mathrm{~F}$ NMR analysis showed the product to be a mixture of at least two isomers (minor) with the 5-silyl isomer (major, ca. $80 \%)$ along with ca. $3 \%$ of $\mathrm{C}_{8} \mathrm{~F}_{17} \mathrm{I} .{ }^{1} \mathrm{H} \mathrm{NMR}\left(\delta, \mathrm{CDCl}_{3}\right): 0.13(\mathrm{~s}$, $4.8 \mathrm{H}, \mathrm{Si}_{2} e_{2}$, major), 0.51 (s, $1.2 \mathrm{H}, \mathrm{SiM} e_{2}$, minor), 3.18 (d, 0.3 $\mathrm{H}, J=1.5 \mathrm{~Hz}, \mathrm{C}_{5} H_{5}$, minor), 3.7 (br, $0.7 \mathrm{H}, \mathrm{C}_{5} H_{5}$, major), 6.4$7.2\left(\mathrm{~m}, 3.5 \mathrm{H}, \mathrm{C}_{5} H_{5}\right) .{ }^{19} \mathrm{~F} \mathrm{NMR}\left(\delta, \mathrm{CDCl}_{3}\right):-81.9\left(\mathrm{t}, 3 \mathrm{~F},{ }^{4} J_{\mathrm{F}, \mathrm{F}}\right.$ $\left.=10 \mathrm{~Hz}, \mathrm{C}^{8} F_{3}\right),-119.2\left(\mathrm{br} \mathrm{s}, 2 \mathrm{~F}, \mathrm{C}^{2} F_{2}\right),-122.5(\mathrm{br} \mathrm{s}, 2 \mathrm{~F}$, $\left.\mathrm{C}^{3} F_{2}\right),-122.7\left(\mathrm{br} \mathrm{s}, 4 \mathrm{~F}, \mathrm{C}^{4,5} F_{2}\right),-123.6\left(\mathrm{br} \mathrm{s}, 2 \mathrm{~F}, \mathrm{C}^{6} F_{2}\right),-126.8$ $\left(\mathrm{t}, 1.5 \mathrm{~F},{ }^{4} J_{\mathrm{F}, \mathrm{F}}=15 \mathrm{~Hz}, \mathrm{C}^{1} F_{2}\right),-127.1\left(\mathrm{~m}, 2 \mathrm{~F}, \mathrm{C}^{7} F_{2}\right),-127.3$ (t, $0.5 \mathrm{~F},{ }^{4} J_{\mathrm{F}, \mathrm{F}}=15 \mathrm{~Hz}, \mathrm{C}^{1} F_{2}$ ).

$[(2,3,4,5,6$-Pentafluorobenzyl)dimethylsilyl $]$ cyclopentadiene (3c). A solution of $\mathrm{LiCp}(1.33 \mathrm{~g}, 18.46 \mathrm{mmol})$ in THF $(20 \mathrm{~mL})$ was added dropwise to a cooled $\left(0{ }^{\circ} \mathrm{C}\right)$ solution of $\mathrm{BrSiMe}_{2}\left(\mathrm{CH}_{2} \mathrm{C}_{6} \mathrm{~F}_{5}\right)(\mathbf{2 c} ; 5.78 \mathrm{~g}, 18.11 \mathrm{mmol})$ in THF $(50 \mathrm{~mL})$. The deep red solution was maintained at $0{ }^{\circ} \mathrm{C}$ for $30 \mathrm{~min}$ and then allowed to come to ambient temperature and left as such overnight. Volatiles were removed in vacuo, and the brown solid was extracted with pentane $(3 \times 20 \mathrm{~mL})$. Filtrate was concentrated in vacuo to give the crude product as an orange oil which was Kugelrohr-distilled $\left(120^{\circ} \mathrm{C}, 10^{-2} \mathrm{mbar}\right)$ to yield a light yellow oil $(4.72 \mathrm{~g}, 86 \%) .{ }^{1} \mathrm{H}$ and ${ }^{13} \mathrm{C} \mathrm{NMR}$ spectra in $\mathrm{CDCl}_{3}$ were extremely complicated, due to the presence of the three isomers. ${ }^{1} \mathrm{H} \mathrm{NMR}\left(\delta, \mathrm{CDCl}_{3}\right)$ : $0.04-0.87$ (3bs, $6 \mathrm{H}$, $\left.\mathrm{SiMe} e_{2}\right), 1.7-2.30\left(3 \mathrm{~m}, 2 \mathrm{H}, \mathrm{CH}_{2}\right), 6.50$ and $6.66\left(2 \mathrm{bs}, 5 \mathrm{H}, \mathrm{C}_{5} \mathrm{H}_{5}\right)$. Anal. Calcd for $\mathrm{C}_{14} \mathrm{H}_{13} \mathrm{~F}_{5} \mathrm{Si}$ : C, 55.25; H, 4.31. Found: C, 55.20; H, 4.28.

[Tris(2,3,4,5,6-pentafluorobenzyl)silyl]cyclopentadiene (3d). A solution of $\mathrm{LiCp}(0.69 \mathrm{~g}, 9.5 \mathrm{mmol})$ in THF (10 $\mathrm{mL})$ was added dropwise to a cooled $\left(0{ }^{\circ} \mathrm{C}\right)$ solution of BrSi$\left(\mathrm{CH}_{2} \mathrm{C}_{6} \mathrm{~F}_{5}\right)_{3}(\mathbf{2 d} ; 5.96 \mathrm{~g}, 9.15 \mathrm{mmol})$ in THF (50 mL). The deep red solution was maintained at $0{ }^{\circ} \mathrm{C}$ for $30 \mathrm{~min}$ and then allowed to come to ambient temperature and left as such overnight. Solvent was removed in vacuo, and pentane $(50 \mathrm{~mL})$ was added. The brown suspension was quenched by water ( 50 $\mathrm{mL})$. The aqueous layer was extracted with pentane $(3 \times 20$ $\mathrm{mL})$, and the organic layers were rinsed with brine $(50 \mathrm{~mL})$, dried over $\mathrm{MgSO}_{4}$, and concentrated in vacuo; the oily crude product was crystallized from pentane $(15 \mathrm{~mL})$ to yield orange microcrystals of the product $(4.71 \mathrm{~g}, 81 \%)$. ${ }^{1} \mathrm{H}$ NMR $(\delta$, $\left.\mathrm{CDCl}_{3}\right): 1.66\left(\mathrm{~m}, 6 \mathrm{H}, \mathrm{CH}_{2}\right), 3.02\left(\mathrm{~d}, 1 \mathrm{H},{ }^{3} J_{\mathrm{H}, \mathrm{H}}=1 \mathrm{~Hz}, \mathrm{C}_{5} \mathrm{H}_{5}\right)$, $6.05\left(\mathrm{~m}, 2 \mathrm{H}, \mathrm{C}_{5} \mathrm{H}_{5}\right)$ and $6.37\left(\mathrm{~m}, 2 \mathrm{H}, \mathrm{C}_{5} \mathrm{H}_{5}\right) .{ }^{13} \mathrm{C}\left\{{ }^{1} \mathrm{H}\right\} \mathrm{NMR}(\delta$, $\left.\mathrm{CDCl}_{3}\right): 7.7\left(\mathrm{CH}_{2}\right), 111.7,130.9,133.7,135.2,140.2,141.9$, and $146.8\left(C_{6} \mathrm{~F}_{5}\right.$ and $\mathrm{C}\left(\mathrm{sp}^{2}\right)$ from $\left.C_{5} \mathrm{H}_{5}\right) .{ }^{19} \mathrm{~F} \mathrm{NMR}\left(\delta, \mathrm{CDCl}_{3}\right):-142.4$ $\left(\mathrm{bd}, 2 \mathrm{~F}, o-\mathrm{C}_{6} \mathrm{~F}_{5}\right),-158.9\left(\mathrm{t}, 1 \mathrm{~F},{ }^{3} J_{\mathrm{F}, \mathrm{F}}=21 \mathrm{~Hz}, p-\mathrm{C}_{6} \mathrm{~F}_{5}\right),-162.8$ (dt, $2 \mathrm{~F},{ }^{3} J_{\mathrm{F}, \mathrm{F}}=22 \mathrm{~Hz}{ }^{4} J_{\mathrm{F}, \mathrm{F}}=7 \mathrm{~Hz}, m-\mathrm{C}_{6} \mathrm{~F}_{5}$ ). Anal. Calcd for $\mathrm{C}_{26} \mathrm{H}_{11} \mathrm{~F}_{15} \mathrm{Si}$ : C, 49.07; H, 1.74. Found: C, 48.98; H, 1.67 .

[Dimethyloctylsilyl]cyclopentadiene (3e). Freshly distilled cyclopentadiene $(2 \mathrm{~mL}, 24.3 \mathrm{mmol}$ ) was added dropwise to a stirred solution of $n$-BuLi $(24.2 \mathrm{mmol})$ in $n$-hexane (100 $\mathrm{mL}$ ) that was kept at $0{ }^{\circ} \mathrm{C}$. The reaction mixture was stirred for $3 \mathrm{~h}$ at room temperature. Then, the solvent was removed and the product was washed with pentane $(3 \times 50 \mathrm{~mL})$ and dried under vacuum. The $\mathrm{Li}\left(\mathrm{C}_{5} \mathrm{H}_{5}\right)$ was then dissolved in THF $(75 \mathrm{~mL})$ at $-78^{\circ} \mathrm{C}$ and the solution added dropwise by cannula to chlorodimethyl(octyl)silane $(4.55 \mathrm{~g}, 22.0 \mathrm{mmol})$ in THF (75 $\mathrm{mL}$ ) at $0{ }^{\circ} \mathrm{C}$ over a period of $0.5 \mathrm{~h}$. The reaction mixture was 
stirred overnight at room temperature. Volatiles were removed under vacuum, and the product was extracted with pentane $(3 \times 50 \mathrm{~mL})$, filtered, and then dried under vacuum, affording $3.41 \mathrm{~g}(66 \%)$ of the pure product as a yellow liquid. GC-MS $(70 \mathrm{eV}): \mathrm{m} / z 236\left(\mathrm{M}^{+}\right)$. As was observed for $\mathrm{C}_{5} \mathrm{H}_{5} \mathrm{SiMe}_{2} \mathrm{C}_{6} \mathrm{~F}_{13}$, this ligand appears as a mixture of three isomers in the ${ }^{1} \mathrm{H}$ NMR spectrum, the 5-isomer being the major compound at room temperature (ca. 80\%). ${ }^{1} \mathrm{H}$ NMR $(200.1 \mathrm{MHz}$, acetone$\left.d_{6}\right): \delta 6.85$ and $6.65\left(2 \times \mathrm{m}, \mathrm{CH}=, 1-\right.$ and $2-\left[\mathrm{C}_{8} \mathrm{H}_{17}(\mathrm{Me})_{2} \mathrm{Si}\right]-$ $\mathrm{C}_{5} \mathrm{H}_{5}, 6.55\left(\mathrm{~m}, \mathrm{CH}=, 5-\left[\mathrm{C}_{8} \mathrm{H}_{17}(\mathrm{Me})_{2} \mathrm{Si}_{\mathrm{C}} \mathrm{C}_{5} \mathrm{H}_{5}\right), 3.47(\mathrm{~m}, 5-\mathrm{CH}\right.$, 5 - $\left.\left[\mathrm{C}_{8} \mathrm{H}_{17}(\mathrm{Me})_{2} \mathrm{Si}\right] \mathrm{C}_{5} \mathrm{H}_{5}\right), 3.03\left(\mathrm{~m}, 5-\mathrm{CH}_{2}, 1-\right.$ and $2-\left[\mathrm{C}_{8} \mathrm{H}_{17}(\mathrm{Me})_{2}-\right.$ $\left.\mathrm{Si}_{5} \mathrm{H}_{5}\right), 1.29\left(\mathrm{~m}, \mathrm{CH}_{3} \mathrm{C}_{6} \mathrm{H}_{12} \mathrm{CH}_{2} \mathrm{Si}, 1-, 2-\right.$, and 5- $\left[\mathrm{C}_{8} \mathrm{H}_{17}(\mathrm{Me})_{2}-\right.$ $\left.\mathrm{Si}_{5} \mathrm{C}_{5}\right), 0.88\left(\mathrm{~m}, \mathrm{CH}_{3} \mathrm{C}_{6} \mathrm{H}_{12} \mathrm{CH}_{2} \mathrm{Si}, 1-, 2-\right.$, and $5-\left[\mathrm{C}_{8} \mathrm{H}_{17}(\mathrm{Me})_{2}-\right.$ $\left.\mathrm{Si}_{5} \mathrm{C}_{5}\right), 0.67\left(\mathrm{~m}, \mathrm{CH}_{2} \mathrm{Si}, 1-\right.$ and $\left.2-\left[\mathrm{C}_{8} \mathrm{H}_{17}(\mathrm{Me})_{2} \mathrm{Si}\right] \mathrm{C}_{5} \mathrm{H}_{5}\right), 0.56$ (m, $\mathrm{CH}_{2} \mathrm{Si}, 5-\left[\mathrm{C}_{8} \mathrm{H}_{17}(\mathrm{Me})_{2} \mathrm{Si}_{\mathrm{C}} \mathrm{C}_{5}\right), 0.15$ (s, $\mathrm{SiMe}_{2}, 1-$ and $2-\left[\mathrm{C}_{8} \mathrm{H}_{17}(\mathrm{Me})_{2} \mathrm{Si}_{\mathrm{C}} \mathrm{C}_{5} \mathrm{H}_{5}\right),-0.09\left(\mathrm{~s}, \mathrm{SiMe}_{2}, 5-\left[\mathrm{C}_{8} \mathrm{H}_{17}(\mathrm{Me})_{2} \mathrm{Si} \mathrm{C}_{5} \mathrm{H}_{5}\right)\right.$.

Bis [ $\{$ dimethyl $(1 H, 1 H, 2 H, 2 H$-perfluorooctyl $)$ silyl $\}$ cyclopentadienyl]zirconium Dichloride $(\mathbf{4 a}) . \mathrm{LiBu}^{\mathrm{n}}(50$ $\mathrm{mL}$ of a $1.6 \mathrm{~mol} \mathrm{~L}^{-1}$ solution in hexane, $80 \mathrm{mmol}$ ) was added to a cooled $\left(0{ }^{\circ} \mathrm{C}\right)$ solution of $\mathrm{C}_{5} \mathrm{H}_{5} \mathrm{SiMe}_{2} \mathrm{C}_{2} \mathrm{H}_{4} \mathrm{C}_{6} \mathrm{~F}_{13}(\mathbf{3 a} ; 37 \mathrm{~g}$, $78.7 \mathrm{mmol})$ in hexane $(200 \mathrm{~mL})$. The resulting reaction mixture was stirred for $3 \mathrm{~h}$ at ambient temperature. The solvent was removed, and the product was washed with pentane $(3 \times 50$ $\mathrm{mL})$ and dried in vacuo. $\mathrm{Li}\left[\mathrm{C}_{5} \mathrm{H}_{5} \mathrm{SiMe}_{2} \mathrm{C}_{2} \mathrm{H}_{4} \mathrm{C}_{6} \mathrm{~F}_{13}\right]$ was dissolved in precooled $\left(-78{ }^{\circ} \mathrm{C}\right) \mathrm{THF}(100 \mathrm{~mL})$ and was added dropwise over $0.5 \mathrm{~h}$ to a cooled $\left(0{ }^{\circ} \mathrm{C}\right)$ solution of $\mathrm{ZrCl}_{4}(9.08 \mathrm{~g}, 38.2 \mathrm{mmol})$ in THF $(100 \mathrm{~mL})$. The resulting solution was stirred for $48 \mathrm{~h}$ at ambient temperature. Volatiles were removed in vacuo, and the residue was extracted with boiling toluene $(100 \mathrm{~mL})$. The filtrate was concentrated in vacuo to afford white thin crystalline needles of pure product $(31.50 \mathrm{~g}, 75 \%)$. Mp: $119-120^{\circ} \mathrm{C}$. ${ }^{1} \mathrm{H}$ NMR $\left(\delta, \mathrm{C}_{6} \mathrm{D}_{6}\right): 0.23\left(\mathrm{~s}, 6 \mathrm{H}, \mathrm{SiMe} e_{2}\right), 0.91\left(\mathrm{~m}, 2 \mathrm{H}, \mathrm{CH}_{2} \mathrm{Si}\right)$, $1.96\left(\mathrm{bm}, 2 \mathrm{H}, \mathrm{CH}_{2}-\mathrm{CF}_{2}\right), 5.78\left(\mathrm{t},{ }^{3} J_{\mathrm{HH}}=2.5 \mathrm{H}, 2 \mathrm{H} \mathrm{z}, \alpha-\mathrm{C}_{5} \mathrm{H}_{4}\right)$, $6.24\left(\mathrm{t},{ }^{3} \mathrm{~J}_{\mathrm{HH}}=2.5 \mathrm{~Hz}, 2 \mathrm{H}, \beta-\mathrm{C}_{5} \mathrm{H}_{4}\right) .{ }^{1} \mathrm{H}$ NMR $\left(\delta\right.$, toluene- $\left.d_{8}\right)$ : 0.23 (s, $6 \mathrm{H}, \mathrm{SiMe} 2), 0.92\left(\mathrm{~m}, 2 \mathrm{H}, \mathrm{CH}_{2} \mathrm{Si}\right), 1.97$ (bm, $2 \mathrm{H}, \mathrm{CH}_{2}-$ $\left.\mathrm{CF}_{2}\right), 5.79\left(\mathrm{t},{ }^{3} J_{\mathrm{HH}}=2.5 \mathrm{~Hz}, 2 \mathrm{H}, \alpha-\mathrm{C}_{5} \mathrm{H}_{4}\right), 6.22\left(\mathrm{t},{ }^{3} J_{\mathrm{HH}}=2.5\right.$ $\left.\mathrm{Hz}, 2 \mathrm{H}, \beta-\mathrm{C}_{5} \mathrm{H}_{4}\right) .{ }^{1} \mathrm{H}$ NMR $\left(\delta\right.$, toluene- $\left.d_{8},-80{ }^{\circ} \mathrm{C}\right): 0.21(\mathrm{~s}, 6$ $\mathrm{H}, \mathrm{SiMe}$ ), 0.94 (vbs, $2 \mathrm{H}, \mathrm{CH}_{2} \mathrm{Si}$ ), 1.97 (vbs, $2 \mathrm{H}, \mathrm{CH}_{2}-\mathrm{CF}_{2}$ ), $5.65\left(\mathrm{bs}, 2 \mathrm{H}, \alpha-\mathrm{C}_{5} \mathrm{H}_{4}\right), 6.08\left(\mathrm{bs}, 2 \mathrm{H}, \beta-\mathrm{C}_{5} \mathrm{H}_{4}\right){ }^{13} \mathrm{C}\left\{{ }^{1} \mathrm{H}\right\} \mathrm{NMR}(\delta$, acetone- $\left.d_{6}\right):-2.3(\mathrm{SiMe}), 6.77\left(\mathrm{CH}_{2} \mathrm{Si}\right), 26.5\left(\mathrm{t},{ }^{2} J_{\mathrm{C}, \mathrm{F}}=23.28\right.$ $\mathrm{Hz}, \mathrm{CH}_{2} \mathrm{CF}_{2}$ ), $117.2\left(\alpha-\mathrm{C} \mathrm{C}_{5} \mathrm{H}_{4}\right), 125.36$ (ipso-C $\left.\mathrm{C}_{5} \mathrm{H}_{4}\right), 127.24$ $\left(\beta-\mathrm{C} \mathrm{C}_{5} \mathrm{H}_{4}\right),{ }^{19} \mathrm{~F}\left\{{ }^{1} \mathrm{H}\right\}$ NMR $\left(\delta\right.$, toluene- $\left.d_{8}\right):-81.2\left(\mathrm{t},{ }^{3} J_{\mathrm{F}, \mathrm{F}}=9\right.$ $\left.\mathrm{Hz}, \mathrm{CF}_{3}\right),-115.6\left(\mathrm{t},{ }^{3} J_{\mathrm{F}, \mathrm{F}}=15 \mathrm{~Hz}, \alpha-\mathrm{CF}_{2}\right),-122.0\left(\mathrm{~s}, \gamma-\mathrm{CF}_{2}\right)$, $-123.0\left(\mathrm{~s}, \delta-\mathrm{CF}_{2}\right),-123.1\left(\mathrm{bs}, \beta-\mathrm{CF}_{2}\right),-126.3\left(\mathrm{bs}, \epsilon-\mathrm{CF}_{2}\right) .{ }^{29} \mathrm{Si}$ NMR (acetone- $d_{6}$ ): $\delta 1.70$ (s). Anal. Calcd for $\mathrm{C}_{30} \mathrm{H}_{28} \mathrm{Cl}_{2} \mathrm{~F}_{26} \mathrm{Si}_{2-}$ $\mathrm{Zr}: \mathrm{C}, 32.73 ; \mathrm{H}, 2.55 ; \mathrm{Cl}, 6.45 ; \mathrm{F}, 44.91 ; \mathrm{Si}, 5.09$. Found: C, 32.58; H, 2.56; Cl, 6.35; F, 44.78; Si, 5.39. MS (TOF-ES): $\mathrm{m} / \mathrm{z}$ $1123\left([\mathrm{M}+\mathrm{Na}]^{+}, 100\right), 2223\left([2 \mathrm{M}+\mathrm{Na}]^{+}\right)$.

Bis[\{dimethyl(perfluorooctyl)silyl\}cyclopentadienyl]zirconium Dichloride (4b). $\mathrm{LiBu}^{\mathrm{n}}\left(4 \mathrm{~mL}\right.$ of a $1.6 \mathrm{~mol} \mathrm{~L}^{-1}$ solution in hexane, $6.4 \mathrm{mmol}$ ) was added to a solution of $\mathrm{C}_{5} \mathrm{H}_{5}$ $\mathrm{SiMe}_{2} \mathrm{C}_{8} \mathrm{H}_{17}(\mathbf{3 b} ; 3.41 \mathrm{~g}, 6.3 \mathrm{mmol})$ in hexane $(50 \mathrm{~mL})$ at ambient temperature. The resulting reaction mixture was stirred for ca. $15 \mathrm{~h}$ at ambient temperature. Solvent was removed by filtration, and the beige solid was rinsed with hexane $(10 \mathrm{~mL})$ and dried in vacuo. The compound was then dissolved in diethyl ether $(30 \mathrm{~mL})$ and solid $\mathrm{ZrCl}_{4}(0.73 \mathrm{~g}, 3.13$ mmol) was added. A cloudy suspension immediately formed and was left at ambient temperature for ca. $20 \mathrm{~h}$. The suspension was filtered and cooled to $-20{ }^{\circ} \mathrm{C}$ to yield pale yellow needles of $4 \mathbf{b}(1.62 \mathrm{~g}, 42 \%)$. Anal. Calcd for $\mathrm{C}_{30} \mathrm{H}_{20} \mathrm{Cl}_{2} \mathrm{~F}_{34^{-}}$ $\mathrm{Si}_{2} \mathrm{Zr}:$ C, 28.95; H, 1.62; Cl, 5.70; Zr, 7.33; Found: C, 29.06; $\mathrm{H}, 1.54 ; \mathrm{Cl}, 5.76 ; \mathrm{Zr}, 7.26$. Mp: $136-137{ }^{\circ} \mathrm{C} .{ }^{1} \mathrm{H}$ NMR $(\delta$, $\left.\mathrm{C}_{6} \mathrm{D}_{6}\right): 0.62\left(\mathrm{~s}, 6 \mathrm{H}, \mathrm{SiMe} e_{2}\right), 5.65\left(\mathrm{bs}, 2 \mathrm{H}, \alpha-\mathrm{C}_{5} \mathrm{H}_{4}\right), 6.31(\mathrm{~s}, 2 \mathrm{H}$, $\left.\beta-\mathrm{C}_{5} \mathrm{H}_{4}\right) .{ }^{1} \mathrm{H}$ NMR $\left(\delta\right.$, toluene- $\left.d_{8}\right): 0.61(\mathrm{~s}, 6 \mathrm{H}, \mathrm{SiMe} 2), 5.70(\mathrm{t}$, $\left.J_{\mathrm{FF}}=2.5 \mathrm{~Hz}, 2 \mathrm{H}, \alpha-\mathrm{C}_{5} \mathrm{H}_{4}\right), 6.30\left(\mathrm{t}, J_{\mathrm{FF}}=2.5 \mathrm{~Hz}, 2 \mathrm{H}, \beta-\mathrm{C}_{5} \mathrm{H}_{4}\right)$. ${ }^{1} \mathrm{H}$ NMR $\left(\delta\right.$, toluene- $\left.d_{8},-80{ }^{\circ} \mathrm{C}\right): 0.64$ and $0.75(2 \mathrm{bs}$, total 6 $\left.\mathrm{H}, \mathrm{SiMe} e_{2}\right), 5.46$ and $5.644\left(2 \mathrm{bs}\right.$, total $\left.2 \mathrm{H}, \alpha-\mathrm{C}_{5} \mathrm{H}_{4}\right), 6.15$ and $6.34\left(2 \mathrm{bs}\right.$, total $\left.2 \mathrm{H}, \beta-\mathrm{C}_{5} \mathrm{H}_{4}\right) .{ }^{13} \mathrm{C}\left\{{ }^{1} \mathrm{H}\right\}$ NMR $\left(\delta\right.$, THF- $\left.d_{8}\right):-5.2$ $\left(\mathrm{SiMe}_{2}\right), 117.2,128.5\left(\alpha, \beta-\mathrm{C}\right.$ of $\left.\mathrm{C}_{5} \mathrm{H}_{4}\right)$, ipso-C of $\mathrm{C}_{5} \mathrm{H}_{4}$ and $\mathrm{C}_{8} \mathrm{~F}_{17}$ signals not observed. ${ }^{19} \mathrm{~F} \operatorname{NMR}\left(\delta, \mathrm{C}_{6} \mathrm{D}_{6}\right):-81.1\left(\mathrm{t}, J_{\mathrm{FF}}=10\right.$
$\mathrm{Hz}, 3 \mathrm{~F}, \mathrm{CF}_{3}$ ), -118.0 (bs, $\left.2 \mathrm{~F}, \alpha-\mathrm{C} F_{2}\right),-121.6$ (br s, $2 \mathrm{~F}, \beta-\mathrm{C} F_{2}$ ), -121.9 (br s, $4 \mathrm{~F}, \gamma, \delta-\mathrm{C} F_{2}$ ), -122.8 (br s, $2 \mathrm{~F}, \zeta-\mathrm{C} F_{2}$ ), -126.3 (br s, $2 \mathrm{~F}, \epsilon-\mathrm{C} F_{2}$ ).

$\operatorname{Bis}[\{(2,3,4,5,6-P e n t a f l u o r o b e n z y l)$ dimethylsilyl $\}$ cyclopentadienyl]zirconium Dichloride (4c). $\mathrm{LiBu}^{\mathrm{n}}(3.4$ $\mathrm{mL}$ of $1.6 \mathrm{~mol} \mathrm{~L}^{-1}$ solution in hexane, $5.44 \mathrm{mmol}$ ) was added to a cooled solution $\left(0{ }^{\circ} \mathrm{C}\right)$ of $\left\{\mathrm{C}_{5} \mathrm{H}_{5} \mathrm{SiMe}_{2}\left(\mathrm{CH}_{2} \mathrm{C}_{6} \mathrm{~F}_{5}\right)\right\}(3 \mathbf{c} ; 1.59$ g, $5.22 \mathrm{mmol})$ in hexane $(20 \mathrm{~mL})$. The beige suspension was left at $0{ }^{\circ} \mathrm{C}$ for $30 \mathrm{~min}$ and then allowed to come to ambient temperature and left for $2 \mathrm{~h}$ as such. The solvent was removed by filtration and the solid rinsed with pentane $(20 \mathrm{~mL})$ and dried in vacuo. The compound was dissolved in diethyl ether $(60 \mathrm{~mL})$, and solid $\mathrm{ZrCl}_{4}(0.48 \mathrm{~g}, 2.05 \mathrm{mmol})$ was added, leading to the exothermic formation of a thick suspension, which was left at ambient temperature overnight. The suspension was filtered off and solvent removed in vacuo to yield the product as an off-white microcrystalline solid (1.53 g, 97\%). Mp: 133$134{ }^{\circ} \mathrm{C} .{ }^{1} \mathrm{H}$ NMR $\left(\delta, \mathrm{C}_{6} \mathrm{D}_{6}\right): 0.33\left(\mathrm{bs}, 6 \mathrm{H}, \mathrm{SiMe}_{2}\right), 2.04(\mathrm{bs}, 2 \mathrm{H}$, $\left.\mathrm{CH}_{2}\right), 5.73\left(\mathrm{t}, 2 \mathrm{H},{ }^{3} J_{\mathrm{H}, \mathrm{H}}=2 \mathrm{~Hz}, \alpha-\mathrm{C}_{5} \mathrm{H}_{4}\right), 6.19\left(\mathrm{t}, 2 \mathrm{H},{ }^{3} \boldsymbol{J}_{\mathrm{H}, \mathrm{H}}=2\right.$ $\left.\mathrm{Hz}, \beta-\mathrm{C}_{5} \mathrm{H}_{4}\right) .{ }^{1} \mathrm{H}$ NMR $\left(\delta\right.$, toluene- $\left.d_{8}\right): 0.32\left(\mathrm{bs}, 6 \mathrm{H}, \mathrm{SiMe}_{2}\right)$, $2.10\left(\mathrm{bs}, 2 \mathrm{H}, \mathrm{CH}_{2}\right), 5.75\left(\mathrm{bs}, 2 \mathrm{H}, \alpha-\mathrm{C}_{5} \mathrm{H}_{4}\right), 6.19\left(\mathrm{bs}, 2 \mathrm{H}, \beta-\mathrm{C}_{5} \mathrm{H}_{4}\right)$. ${ }^{1} \mathrm{H}$ NMR $\left(\delta\right.$, toluene- $\left.d_{8},-80{ }^{\circ} \mathrm{C}\right): 0.40\left(\mathrm{bs}, 6 \mathrm{H}, \mathrm{SiMe}_{2}\right), 2.10$ (bs, $\left.2 \mathrm{H}, \mathrm{CH}_{2}\right), 5.55\left(\mathrm{bs}, 2 \mathrm{H}, \alpha-\mathrm{C}_{5} \mathrm{H}_{4}\right), 6.12\left(\mathrm{bs}, 2 \mathrm{H}, \beta-\mathrm{C}_{5} \mathrm{H}_{4}\right) .{ }^{13} \mathrm{C}$ $\operatorname{NMR}\left(\delta, \mathrm{C}_{6} \mathrm{D}_{6}\right):-2.5\left(\mathrm{~s}, \mathrm{SiMe}_{2}\right), 13.3\left(\mathrm{~s}, \mathrm{CH}_{2}\right), 114.6,126.1$, 128.3, and $143.0\left(\mathrm{C}_{6} \mathrm{~F}_{5}\right) .{ }^{19} \mathrm{~F} \mathrm{NMR}\left(\delta, \mathrm{C}_{6} \mathrm{D}_{6}\right):-143.1\left(\mathrm{~d},{ }^{3} \boldsymbol{J}_{\mathrm{F}, \mathrm{F}}=\right.$ $20 \mathrm{~Hz}, 2 \mathrm{~F}, o-\mathrm{F}),-160.8\left(\mathrm{t},{ }^{3} J_{\mathrm{F}, \mathrm{F}}=20 \mathrm{~Hz}, 1 \mathrm{~F}, p-\mathrm{F}\right),-163.9(\mathrm{dt}$, $\left.{ }^{3} J_{\mathrm{F}, \mathrm{F}}=20 \mathrm{~Hz}, 2 \mathrm{~F}, m-\mathrm{F}\right)$, Anal. Calcd for $\mathrm{C}_{28} \mathrm{H}_{24} \mathrm{Cl}_{2} \mathrm{~F}_{10} \mathrm{Si}_{2} \mathrm{Zr}$ : C, 43.74; H, 3.15. Found: C, 44.02; H, 3.35

Bis $[\{$ tris $(2,3,4,5,6$-pentafluorobenzyl $)$ silyl $\}$ cyclopentadienyl]zirconium Dichloride (4d). $\mathrm{LiBu}^{\mathrm{n}}(2.3 \mathrm{~mL}$ of $1.6 \mathrm{~mol}$ $\mathrm{L}^{-1}$ solution in hexane, $3.68 \mathrm{mmol}$ ) was added to a cooled solution $\left(0{ }^{\circ} \mathrm{C}\right)$ of $\left\{\mathrm{C}_{5} \mathrm{H}_{5} \mathrm{Si}\left(\mathrm{CH}_{2} \mathrm{C}_{6} \mathrm{~F}_{5}\right)_{3}\right\}(\mathbf{3 d} ; 2.14 \mathrm{~g}, 3.36 \mathrm{mmol})$ in hexane $(50 \mathrm{~mL})$. The light beige suspension was left at 0 ${ }^{\circ} \mathrm{C}$ for $30 \mathrm{~min}$ and then allowed to come to ambient temperature and left for $2 \mathrm{~h}$ as such. The solvent was removed by filtration and the solid rinsed with pentane $(20 \mathrm{~mL})$ and dried in vacuo. The compound was dissolved in diethyl ether $(40 \mathrm{~mL})$, and solid $\mathrm{ZrCl}_{4}(0.31 \mathrm{~g}, 1.33 \mathrm{mmol})$ was added, leading to the exothermic formation of a thick suspension, which was left at ambient temperature overnight. The suspension was filtered off and solvent removed in vacuo to yield the product as an off-white microcrystalline solid $(1.71 \mathrm{~g}, 93 \%)$. Mp: $55-56{ }^{\circ} \mathrm{C}$. ${ }^{1} \mathrm{H} \operatorname{NMR}\left(\delta, \mathrm{C}_{6} \mathrm{D}_{6}\right): 2.34\left(\mathrm{bs}, 6 \mathrm{H}, \mathrm{CH}_{2}\right), 5.36\left(\mathrm{t}, 2 \mathrm{H},{ }^{3} J_{\mathrm{H}, \mathrm{H}}=3\right.$ $\left.\mathrm{Hz}, \alpha-\mathrm{C}_{5} \mathrm{H}_{4}\right), 6.13\left(\mathrm{t}, 2 \mathrm{H},{ }^{3} \mathrm{~J}_{\mathrm{HH}}=3 \mathrm{~Hz}, \beta-\mathrm{C}_{5} \mathrm{H}_{4}\right) .{ }^{13} \mathrm{C} \mathrm{NMR}(\delta$, $\left.\mathrm{C}_{6} \mathrm{D}_{6}\right): 8.8\left(\mathrm{CH}_{2}\right), 111.9,114.2,122.4,125.3,140.2,141.9$, and $146.8\left(C_{6} \mathrm{~F}_{5}\right.$ and $\left.C_{5} \mathrm{H}_{4}\right)$. Anal. Calcd for $\mathrm{C}_{52} \mathrm{H}_{20} \mathrm{Cl}_{2} \mathrm{~F}_{30} \mathrm{Si}_{2} \mathrm{Zr}$ : C, 43.58; H, 1.41. Found: C, 43.45; H, 1.33

Bis[(dimethyloctylsilyl)cyclopentadienyl]zirconium Dichloride (4e). To a stirred solution of $\mathrm{LiBu}^{\mathrm{n}}(14.2 \mathrm{mmol}$, in $8.9 \mathrm{~mL}$ of $n$-hexane) in $\mathrm{Et}_{2} \mathrm{O}(150 \mathrm{~mL})$ was added $\mathrm{C}_{5} \mathrm{H}_{5^{-}}$ $\mathrm{SiMe}_{2} \mathrm{C}_{8} \mathrm{H}_{17}(3.37 \mathrm{~g}, 14.2 \mathrm{mmol})$ at $-78{ }^{\circ} \mathrm{C}$. The resulting reaction mixture was stirred for $3 \mathrm{~h}$ at room temperature. Volatiles were removed under vacuum. The yellow viscous liquid obtained could not be washed with pentane or hexane, because it gave a gel instead of a precipitate in these solvents. The lithiated product was dissolved in THF $(75 \mathrm{~mL})$ at -78 ${ }^{\circ} \mathrm{C}$. A solution of $\mathrm{ZrCl}_{4}(1.64 \mathrm{~g}, 6.90 \mathrm{mmol})$ in $\mathrm{THF}(75 \mathrm{~mL})$ was prepared, and the THF solution of the lithiated ligand was added dropwise over $0.5 \mathrm{~h}$ at $0{ }^{\circ} \mathrm{C}$. The mixture was stirred for $48 \mathrm{~h}$ at room temperature. Volatiles were removed under vacuum, and the residue was extracted with pentane $(2 \times 50$ $\mathrm{mL}$ ). Concentration of the orange extract under vacuum afforded a brown oil (4.43 g, 98\%). ${ }^{1} \mathrm{H}$ NMR $(300.1 \mathrm{MHz}$, acetone- $\left.d_{6}\right): \delta 6.76(\mathrm{~m}, 4 \mathrm{H}, \mathrm{CH}=), 1.31\left(\mathrm{~m}, 12 \mathrm{H}, \mathrm{CH}_{3} \mathrm{C}_{6} \mathrm{H}_{12^{-}}\right.$ $\left.\mathrm{CH}_{2} \mathrm{Si}\right), 0.91\left(\mathrm{~m}, 3 \mathrm{H}, \mathrm{CH}_{3} \mathrm{C}_{6} \mathrm{H}_{12} \mathrm{CH}_{2} \mathrm{Si}\right), 0.80\left(\mathrm{~m}, 2 \mathrm{H}, \mathrm{CH}_{2} \mathrm{Si}\right)$, $0.34\left(\mathrm{~s}, 6 \mathrm{H},\left(\mathrm{CH}_{3}\right)_{2} \mathrm{Si}\right) .{ }^{13} \mathrm{C}\left\{{ }^{1} \mathrm{H}\right\} \mathrm{NMR}\left(75.5 \mathrm{MHz}\right.$, acetone- $\left.d_{6}\right)$ : $126.85(\mathrm{CH}=), 126.70(\mathrm{C}=), 117.23(\mathrm{CH}=), 34.30,32.70,30.03$ (high intensity, probably two overlapping signals), 24.56, 23.39 $\left(\mathrm{CH}_{3} \mathrm{C}_{6} \mathrm{H}_{12} \mathrm{CH}_{2} \mathrm{Si}\right), 17.43,14.46\left(2 \mathrm{C}, \mathrm{CH}_{3} \mathrm{C}_{6} \mathrm{H}_{12} \mathrm{CH}_{2} \mathrm{Si}\right),-1.78$ $\left(\mathrm{Si}\left(\mathrm{CH}_{3}\right)_{2}\right) .{ }^{29} \mathrm{Si} \mathrm{NMR}\left(59.6 \mathrm{MHz}\right.$, acetone- $\left.d_{6}\right): \delta 0.37\left(\mathrm{~s}, \mathrm{SiMe}_{2}\right)$. ${ }^{29} \mathrm{Si}$ NMR (59.6 MHz, benzene- $\left.d_{6}\right): \delta-4.76\left(\mathrm{~s}, \mathrm{SiMe}_{2}\right)$. Anal. 
Table 3. Catalyst NMR Analysis of $(4 a-c, f)-M A O$

\begin{tabular}{|c|c|c|c|c|c|}
\hline \multirow[b]{2}{*}{ compd } & \multicolumn{5}{|c|}{${ }^{1} \mathrm{H}(\delta, \mathrm{ppm})^{a}$} \\
\hline & $\mathrm{Cp}$ & $\mathrm{CH}_{2}$ & $\mathrm{SiMe}_{2}$ & $\mathrm{Zr}-\mathrm{Me}$ & MAO \\
\hline $4 \mathbf{a}$ & $6.24(\mathrm{t}), 5.78(\mathrm{t})$ & $1.96(\mathrm{~m}), 0.91(\mathrm{~m})$ & $0.23(\mathrm{~s})$ & & \\
\hline $\mathbf{4 a}+\mathrm{MAO}^{b}$ & $\begin{array}{l}6.28(\mathrm{~s}), 6.24(\mathrm{~s}), 5.85(\mathrm{~s}), 5.78(\mathrm{~s}) \\
\quad 5.75(\mathrm{~s}), 5.51(\mathrm{~s})\end{array}$ & $\begin{array}{l}2.01(\mathrm{~s}), 1.94(\mathrm{~s}) \\
\quad 0.95(\mathrm{~s}), 0.91(\mathrm{~s})\end{array}$ & $0.24(\mathrm{~s}), 0.18(\mathrm{~s})$ & $0.42(\mathrm{bs})$ & $-0.16(\mathrm{bs})$ \\
\hline 4b & $6.31(\mathrm{t}), 5.65(\mathrm{t})$ & & $0.62(\mathrm{~s})$ & & \\
\hline $\mathbf{4 b}+\mathrm{MAO}^{b}$ & $6.48(\mathrm{~b}), 5.93(\mathrm{~b}), 5.62(\mathrm{~b}), 5.42(\mathrm{~b})$ & & $0.57(\mathrm{~s})$ & $0.50(\mathrm{~s})$ & $-0.33(\mathrm{bs})$ \\
\hline $\mathbf{4 b}+\mathrm{MAO}^{c}$ & $6.55(\mathrm{~s}), 5.97(\mathrm{~s}), 5.65(\mathrm{~s}), 5.45(\mathrm{~s})$ & & $0.57(\mathrm{~s})$ & $0.39(\mathrm{~s})$ & $-0.27(\mathrm{bs}), 0.49(\mathrm{~s})$ \\
\hline 4c & $6.19(\mathrm{t}), 5.73(\mathrm{t})$ & $2.04(\mathrm{~s})$ & $0.33(\mathrm{~s})$ & & \\
\hline $\mathbf{4 c}+\mathrm{MAO}^{b}$ & $6.22(\mathrm{~b}), 5.89(\mathrm{~b}), 5.79(\mathrm{~b}), 5.58(\mathrm{~b})$ & $2.02(\mathrm{~s})$ & $0.26(\mathrm{~s})$ & $0.44(\mathrm{~s})$ & $-0.32(\mathrm{bs}),-0.56(\mathrm{~s})$ \\
\hline $\mathbf{4 c}+\mathrm{MAO}^{c}$ & $6.31(\mathrm{~s}), 5.90(\mathrm{~s}), 5.77(\mathrm{~s}), 5.12(\mathrm{~s})$ & $2.08(\mathrm{~s})$ & $0.26(\mathrm{~s})$ & $0.42(\mathrm{~s})$ & $-0.26(\mathrm{bs}),-0.50(\mathrm{~s})$ \\
\hline 4f & $6.35(\mathrm{t}), 5.90(\mathrm{t})$ & & $0.28(\mathrm{~s})$ & & \\
\hline $\mathbf{4 f}+\mathrm{MAO}^{b}$ & $6.32(\mathrm{~b}), 6.02(\mathrm{~s}), 5.89(\mathrm{~s}), 5.78(\mathrm{~s}), 5.66(\mathrm{~s})$ & & $0.24(\mathrm{~s}), 0.11(\mathrm{~s})$ & $0.49(\mathrm{~s})$ & $-0.22(\mathrm{bs})$ \\
\hline
\end{tabular}

Calcd for $\mathrm{C}_{30} \mathrm{H}_{54} \mathrm{Cl}_{2} \mathrm{Si}_{2} \mathrm{Zr}$ : C, 56.88; H, 8.53; Cl, 11.22; Si, 8.85. Found: C, 56.68; H, 8.46; Cl, 11.27; Si, 8.88.

Bis [ $\{$ dimethyl $(1 H, 1 H, 2 H, 2 H$-perfluorooctyl $)$ silyl $\}$ cyclopentadienyl]zirconium Dimethyl (5a). To a stirred solution of $4 \mathbf{a}(6.39 \mathrm{~g}, 5.8 \mathrm{mmol})$ in diethyl ether $(100 \mathrm{~mL})$ was added a solution of LiMe (11.68 $\mathrm{mmol})$ in diethyl ether at -78 ${ }^{\circ} \mathrm{C}$. The solution was warmed to room temperature and stirred overnight. The volatiles were removed under vacuum, and the product was extracted with pentane $(150 \mathrm{~mL})$ and then dried under vacuum. The pure product $(5.31 \mathrm{~g}, 86 \%)$ was obtained as a white powder and recrystallized from pentane. ${ }^{1} \mathrm{H}$ NMR $\left(200.14 \mathrm{MHz}\right.$, benzene- $\left.d_{6}\right): \delta 5.95$ and $5.84\left(\mathrm{dt}, 4 \mathrm{H}, J_{\mathrm{AX}}=J_{\mathrm{AX}^{\prime}}\right.$ $=2.45 \mathrm{~Hz}, \mathrm{CH}=), 1.94\left(\mathrm{~m}, 2 \mathrm{H}, \mathrm{CH}_{2}-\mathrm{CF}_{2}\right), 0.81\left(\mathrm{~m}, 2 \mathrm{H}, \mathrm{CH}_{2}-\right.$ $\mathrm{Si}), 0.07\left(\mathrm{~s}, 6 \mathrm{H}, \mathrm{Me}_{2} \mathrm{Si}\right),-0.21\left(\mathrm{~s}, 3 \mathrm{H}, \mathrm{Me}_{2} \mathrm{Zr}\right) .{ }^{13} \mathrm{C}\left\{{ }^{1} \mathrm{H}\right\} \mathrm{NMR}$ $\left(50.33 \mathrm{MHz}\right.$, benzene- $\left.d_{6}\right)$ : $\delta 118.42(\mathrm{CH}=), 117.22(\mathrm{C}=), 113.91$ $(\mathrm{CH}=), 31.57\left(\mathrm{Me}_{2} \mathrm{Zr}\right), 26.69\left(\mathrm{t},{ }^{2} J_{\mathrm{C}, \mathrm{F}}=23.73 \mathrm{~Hz}, \mathrm{CH}_{2}-\mathrm{CF}_{2}\right)$, $7.51\left(\mathrm{CH}_{2}-\mathrm{Si}\right),-2.50\left(\mathrm{Si}\left(\mathrm{CH}_{3}\right)_{2}\right)$. ${ }^{29} \mathrm{Si} \mathrm{NMR}(59.62 \mathrm{MHz}$, benzene- $\left.d_{6}\right)$ : $\delta-4.71\left(\mathrm{SiMe}_{2}\right)$. Anal. Calcd for $\mathrm{C}_{32} \mathrm{H}_{34} \mathrm{Cl}_{2} \mathrm{~F}_{26^{-}}$ $\mathrm{Si}_{2} \mathrm{Zr}$ : C, 36.26; H, 3.21; Cl, 0.00; F, 46.65; Si, 5.29. Found: C, 36.15; H, 3.15; Cl, 0.00; F, 46.43; Si, 5.24.

NMR Analysis of Precatalyst/MAO Mixtures. In a typical experiment, ca. $5 \mu \mathrm{mol}$ of the precatalyst was added in a Schlenk to solid MAO $(0.3 \mathrm{~mL}$ of a $10 \mathrm{wt} \%$ solution in toluene evaporated to dryness in vacuo, $0.5 \mathrm{mmol}, \mathrm{Al} / \mathrm{Zr} \approx 100$ ), solvated with $\mathrm{C}_{6} \mathrm{D}_{6}$ (ca. $0.5 \mathrm{~mL}$ ), and transferred under nitrogen to an NMR tube, which was then capped. Hydrolysis of the catalyst was carried out with $0.1 \mathrm{~mL}$ of a $1: 20$ concentrated $\mathrm{HCl}-\mathrm{D}_{2} \mathrm{O}$ solution. See Table 3 for chemical shifts and assignments.

Ethylene Polymerization. In a typical polymerization experiment, a jacketed $150 \mathrm{~mL}$ glass reactor was fitted with a gas action stirrer (1300 rpm) and inlet/outlet for ethylene/ vacuum/nitrogen. The reactor was thermostated at $20^{\circ} \mathrm{C}$ using a water bath, dried and degassed in vacuo for $30 \mathrm{~min}$, and then purged with nitrogen gas. The solvent was transferred via syringe, and a solution (in toluene, hexane, or FC-72) of the catalyst was added (the total volume of solvents was used for calculation of the zirconium concentration). Finally MAO (10 wt \% solution in toluene or suspension in hexane) was transferred to the reaction mixture, which was stirred for 5 min under nitrogen pressure. The reactor was briefly depressurized, and ethylene was allowed at 1.1 bar pressure (at $t_{0}$ ). The reaction was quenched (at $t_{\mathrm{f}}$ ) with $50 \mathrm{~mL}$ of a 1:1 mixture of $\mathrm{EtOH}$ and aqueous $2 \mathrm{M} \mathrm{HCl}$ and stirred for $15 \mathrm{~min}$. The suspension was filtered off, and the solid was rinsed with $10 \%$ aqueous $\mathrm{HCl}$ and then $\mathrm{EtOH}$ and dried in vacuo for ca. $15 \mathrm{~h}$ at ambient temperature.

Determination of Partition Coefficients. The partition coefficients were determined by dissolving a known amount of complex (typically $50 \mu \mathrm{mol}$ ) in a fluorous biphasic system consisting of $c-\mathrm{C}_{6} \mathrm{~F}_{11} \mathrm{CF}_{3}(2.00 \pm 0.01 \mathrm{~mL})$ and toluene $(2.00 \pm$ $0.01 \mathrm{~mL}$ ). The resulting mixture was stirred at $20^{\circ} \mathrm{C}$ for $1 \mathrm{~h}$, and then an aliquot of each layer was removed for ICP-AAS analysis on silicon with an accuracy of $\pm 3 \mathrm{ppm}$. A conservative

Table 4. Crystallographic Data for $2 d$ and $4 a, c$

\begin{tabular}{|c|c|c|c|}
\hline & 2d & $4 \mathbf{a}$ & $4 c$ \\
\hline empirical formula & $\begin{array}{l}\mathrm{C}_{21} \mathrm{H}_{6} \mathrm{BrF}_{15^{-}} \\
\mathrm{Si}\end{array}$ & $\begin{array}{l}\mathrm{C}_{30} \mathrm{H}_{28} \mathrm{Cl}_{2} \mathrm{~F}_{26^{-}} \\
\mathrm{Si}_{2} \mathrm{Zr}\end{array}$ & $\begin{array}{l}\mathrm{C}_{28} \mathrm{H}_{24} \mathrm{Cl}_{2} \mathrm{~F}_{10} \\
\mathrm{Si}_{2} \mathrm{Zr}\end{array}$ \\
\hline formula wt & 651.26 & 1100.82 & 768.77 \\
\hline cryst syst & trigonal & monoclinic & triclinic \\
\hline space group & $R \overline{3}$ (No. 148) & $C 2 / c$ (No. 15) & $P \overline{1}$ (No. 2) \\
\hline$a, \AA$ & $15.9230(12)$ & $46.3678(10)$ & $7.8842(1)$ \\
\hline$b, \AA$ & $15.9230(12)$ & $6.5983(2)$ & $13.4155(2)$ \\
\hline$c, \AA$ & $29.4013(16)$ & $14.2962(4)$ & $15.1449(3)$ \\
\hline$\alpha, \operatorname{deg}$ & 90 & 90 & $73.4706(7)$ \\
\hline$\beta, \operatorname{deg}$ & 90 & $106.4326(14)$ & $80.0282(8)$ \\
\hline$\gamma, \mathrm{deg}$ & 120 & 90 & $87.9965(7)$ \\
\hline$V, \AA^{3}$ & $6455.8(8)$ & $4195.2(2)$ & $1512.31(4)$ \\
\hline$Z$ & 12 & 4 & 2 \\
\hline$D_{\text {calcd }}, \mathrm{g} \mathrm{cm}^{-3}$ & 2.010 & 1.743 & 1.688 \\
\hline$\mu(\mathrm{Mo} \mathrm{K} \alpha), \mathrm{mm}^{-1}$ & 2.106 & 0.586 & 0.701 \\
\hline$F(000)$ & 3792 & 2176 & 768 \\
\hline $\begin{array}{l}\text { no. of unique } \\
\text { reflns, } R_{\text {int }}\end{array}$ & $2966,0.064$ & $4790,0.065$ & $5631,0.041$ \\
\hline no. of $\operatorname{rflns}(I>2 \sigma(I))$ & 2249 & 2810 & 4883 \\
\hline final R1 $(I>2 \sigma(I))$ & 0.036 & 0.033 & 0.030 \\
\hline final wR2 & 0.078 & 0.089 & 0.079 \\
\hline goodness of fit & 1.015 & 0.80 & 1.05 \\
\hline
\end{tabular}

estimate of the experimental error in the partition coefficient is \pm 1 in the last digit.

Crystallography. Colorless, X-ray-quality, single crystals of the zirconocene dichloride were grown from cooled (ca. -20 $\left.{ }^{\circ} \mathrm{C}\right)$ concentrated $\mathrm{Et}_{2} \mathrm{O}(\mathbf{2 d}), \mathrm{THF}(\mathbf{4 a})$, or $\mathrm{Et}_{2} \mathrm{O}(\mathbf{4 c})$ solution of the pure compound and were mounted under a flow of cold nitrogen $(150 \mathrm{~K})$ on an Enraf-Nonius CAD4T (2d) or a Nonius KappaCCD (4a,c) diffractometer, both equipped with a rotating anode. Crystal data and details on data collection are collected in Table 4. Data were collected using graphitemonochromated Mo $\mathrm{K} \alpha$ radiation $(\lambda=0.71073 \AA)$. The structures were solved by direct methods $\left(\mathbf{2 d}^{39}\right.$ and $\left.\mathbf{4} \mathbf{a}^{40}\right)$ or Patterson methods $\left(\mathbf{4} \mathbf{c}^{41}\right)$ and refined with SHELXL-9742 against $F^{2}$ of all reflections. All geometrical calculations and illustrations were done with PLATON. ${ }^{43}$

Acknowledgment. We thank the European Commission for the award of a RTN fellowship to P.G.M. (Contract HPRN-CT-2000-00010), ELF SA for a CSN

(39) Sheldrick, G. M. SHELXS-86; Universität Göttingen, Göttingen, Germany, 1986 .

(40) Altomare, A.; Burla, M. C.; Camalli, M.; Cascarano, G. L.; Giacovazzo, C.; Guagliardi, A.; Moliterni, A. G. G.; Polidori, G.; Spagna, R. J. Appl. Crystallogr. 1999, 32, 115-119.

(41) Beurskens, P. T.; Admiraal, G.; Beurskens, G.; Bosman, W. P.; Garcia-Granda, S.; Gould, R. O., Smits, J. M. M.; Smykalla, C. The DIRDIF99 program system; Technical Report of the Crystallography Laboratory, University of Nijmegen, Nijmegen, The Netherlands, 1999. (42) Sheldrick, G. M. SHELXL-97; Universität Göttingen, Göttingen, Germany, 1997.

(43) Spek, A. L. J. Appl. Crystallogr. 2003, 36, 7-13. 
studentship to V.C., and ARKEMA Vlissingen for other support. M.L. and A.L.S. were supported by The Netherlands Organization for Scientific Research (NWO/ CW). We thank Professors J. H. Teuben and B. Hessen (COP Centre, University of Groningen) for initial screening of polymerization activity.
Supporting Information Available: CIF files with atomic coordinates, bond lengths and angles, and thermal parameters for $\mathbf{2 d}$ and $\mathbf{4 a}, \mathbf{c}$ and figures giving ${ }^{1} \mathrm{H}$ NMR spectra of solutions of $4 \mathbf{a}-\mathbf{c}$ with MAO $(\mathrm{Al} / \mathrm{Zr}=100)$ in benzene- $d_{6}$. This material is available free of charge via the Internet at http://pubs.acs.org.

OM049507Z 